\title{
Reversible Pathologic and Cognitive Phenotypes in an Inducible Model of Alzheimer-Amyloidosis
}

\author{
Tatiana Melnikova, ${ }^{1 \star}$ Susan Fromholt, ${ }^{2 \star}$ HyunSu Kim, ${ }^{1}$ Deidre Lee, ${ }^{1}$ Guilian Xu, ${ }^{2}$ Ashleigh Price, ${ }^{2}$ Brenda D. Moore, ${ }^{2}$ \\ Todd E. Golde, ${ }^{2}$ Kevin M. Felsenstein, ${ }^{2}$ Alena Savonenko, ${ }^{1,3}$ and David R. Borchelt ${ }^{2}$ \\ Departments of ${ }^{1}$ Pathology and ${ }^{3}$ Neurology, Johns Hopkins University School of Medicine, Baltimore, Maryland 21205, and ${ }^{2}$ Department of Neuroscience, \\ Center for Translational Research in Neurodegenerative Disease, McKnight Brain Institute, University of Florida, Gainesville, Florida 32610
}

\begin{abstract}
Transgenic mice that express mutant amyloid precursor protein (APPsi) using tet-Off vector systems provide an alternative model for assessing short- and long-term effects of $\mathrm{A} \beta$-targeting therapies on phenotypes related to the deposition of Alzheimer-type amyloid. Here we use such a model, termed APPsi:tTA, to determine what phenotypes persist in mice with high amyloid burden after new production of APP/A $\beta$ has been suppressed. We find that 12- to 13-month-old APPsi:tTA mice are impaired in cognitive tasks that assess short- and long-term memories. Acutely suppressing new APPsi/A $\beta$ production produced highly significant improvements in performing shortterm spatial memory tasks, which upon continued suppression translated to superior performance in more demanding tasks that assess long-term spatial memory and working memory. Deficits in episodic-like memory and cognitive flexibility, however, were more persistent. Arresting mutant APPsi production caused a rapid decline in the brain levels of soluble APP ectodomains, full-length APP, and APP C-terminal fragments. As expected, amyloid deposits persisted after new APP/A $\beta$ production was inhibited, whereas, unexpectedly, we detected persistent pools of solubilizable, relatively mobile, $A \beta 42$. Additionally, we observed persistent levels of $A \beta$-immunoreactive entities that were of a size consistent with SDS-resistant oligomeric assemblies. Thus, in this model with significant amyloid pathology, a rapid amelioration of cognitive deficits was observed despite persistent levels of oligomeric $A \beta$ assemblies and low, but detectable solubilizable $\mathrm{A} \beta 42$ peptides. These findings implicate complex relationships between accumulating A $\beta$ and activities of APP, soluble APP ectodomains, and/or APP C-terminal fragments in mediating cognitive deficits in this model of amyloidosis.
\end{abstract}

\section{Introduction}

Multiple lines of genetic evidence link the accumulation and/or deposition of amyloid $\beta$ peptide $(A \beta)$ as a causative factor in Alzheimer's disease (AD) (for review, see Selkoe and Podlisny, 2002). Disease-causing mutations in the amyloid precursor protein (APP), which produces the $\mathrm{A} \beta$ peptide through a series of proteolytic events (for review, see Lichtenthaler et al., 2011), generally lead to enhanced levels of A $\beta 42$ peptides (Citron et al., 1992, 1997; Suzuki et al., 1994; Scheuner et al., 1996; Kwok et al., 2000; De Jonghe et al., 2001; Bentahir et al., 2006; Di et al., 2009; Zhou et al., 2011). This longer A $\beta$

Received Sept. 5, 2012; revised Nov. 15, 2012; accepted Dec. 17, 2012.

Author contributions: D.R.B. and A.S. designed research; T.M., S.F., H.S.K., D.L., G.X., A.P., B.D.M., K.M.F., and A.S. performed research; T.E.G. contributed unpublished reagents/analytic tools; T.M., G.X., T.E.G., K.M.F., A.S., and D.R.B. analyzed data; A.S. and D.R.B. wrote the paper.

This work was supported by National Institute of Neurological Disease and Stroke Grant 5R01NS047225-08 to D.R.B. and A.S., the National Institutes on Aging ADRC Grant P50AG005146 to A.V.S., the Illana Starr Scholar Fund (A.V.S.), and the SantaFe HealthCare Alzheimer's Disease Center. We thank Christopher Janus and Paramita Chakrabarty for helpful discussions; S. Om, L.-T. Lin, S. Rutenberg, E. Cho, and Y.-J. Choi for technical support; 0. Atassi, E. Banks, G. Brar, J. Kim, R. Linker, S. Min, A. Murphy, and 0. Tong for help with behavioral testing and data handling; and Johns Hopkins University research animal resource unit for supportive care of the transgenic mouse models.

The authors declare no competing financial interests.

*T.M. and S.F. contributed equally to this work.

This article is freely available online through the J Neurosci Open Choice option.

Correspondence should be addressed to either of the following: Dr. Alena Savonenko, Department of Pathology, Johns Hopkins University School of Medicine, 558 Ross Research Building, 720 Rutland Avenue, Baltimore, MD 21205, E-mail: asavone1@jhmi.edu; or Dr. David R. Borchelt, Department of Neuroscience, University of Florida, 1275 Center Drive, Box 100159, Gainesville, FL 32610, E-mail: drb1@ufl.edu.

DOI:10.1523/JNEUROSCI.4251-12.2013

Copyright $\odot 2013$ the authors $\quad 0270-6474 / 13 / 333765-15 \$ 15.00 / 0$ peptide is most prone to produce amyloid deposits (Iwatsubo et al., 1994; McGowan et al., 2005). Early-onset familial AD is also associated with mutations in two functionally related proteins termed presenilin 1 and 2 (Rogaev et al., 1995), which are interchangeable components of $\gamma$-secretase, the multiprotein complex that catalyzes one of the critical proteolytic events that produces A $\beta 42$ (for review, see Li et al., 2009). Transgenic mice that express mutant APP, or mutant APP with mutant PS1, develop Alzheimer-type amyloidosis and memory dysfunction (for review, see Jankowsky et al., 2002; Eriksen and Janus, 2007).

No consensus has emerged regarding the basis for memory dysfunction in mice that model Alzheimer amyloidosis. In some cases, memory impairment appears after amyloid burden reaches moderate to severe levels (Savonenko et al., 2005; Eriksen and Janus, 2007) and others report memory dysfunction before amyloid deposition occurs or reaches moderate levels (Hsiao et al., 1996; Dodart et al., 1999; Moechars et al., 1999; Chen et al., 2000; Janus et al., 2000; Westerman et al., 2002). In multiple studies, memory dysfunction has been correlated to the appearance of soluble oligomeric assemblies of $\mathrm{A} \beta$, including dodecameric assemblies (Westerman et al., 2002), dimeric assemblies of $A \beta 42$ (Klyubin et al., 2008; McDonald et al., 2010), and much larger assemblies that may mediate cognitive performance in mouse models by direct interaction with the normal cellular prion protein $\left(\mathrm{PrP}^{\mathrm{C}}\right)$ (Gimbel et al., 2010).

In the present study, we used a mouse model of Alzheimertype amyloidosis (APPsi:tTA) in which the deposition of $A \beta$ is 

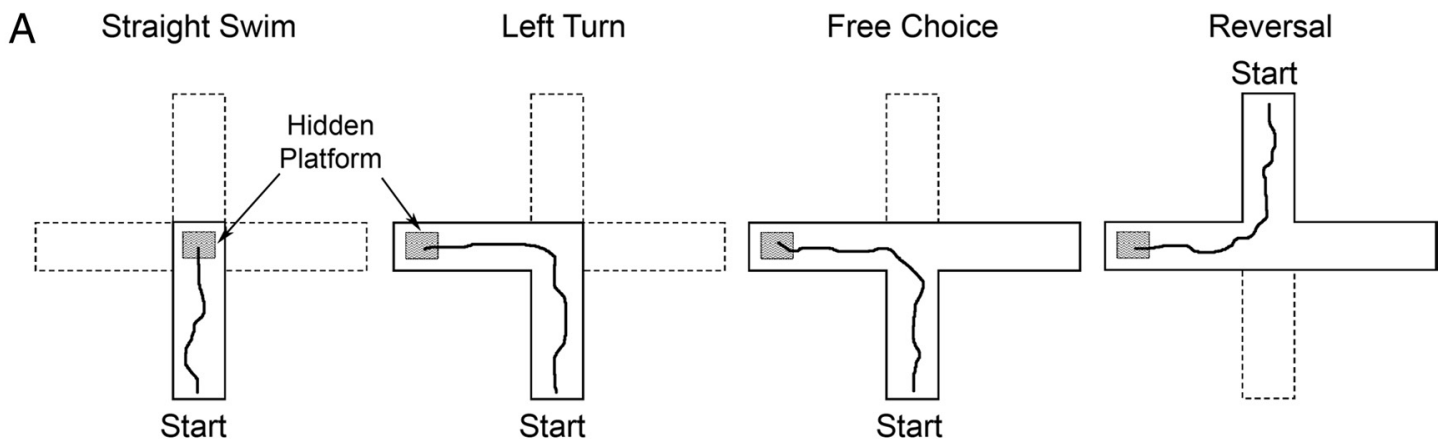

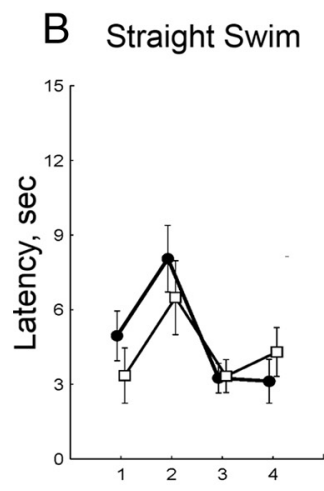

Stage 1

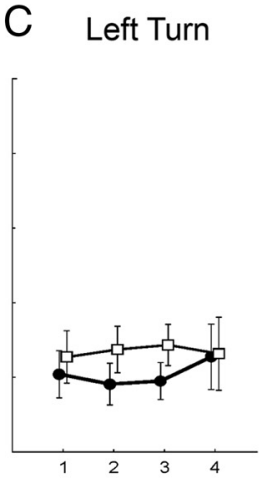

Stage 2

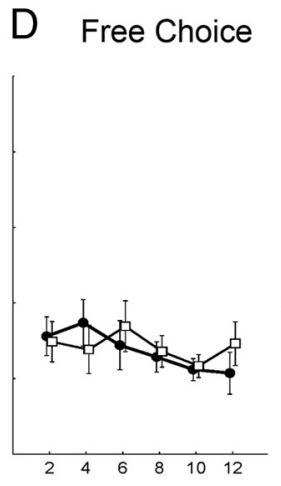

Stage 3

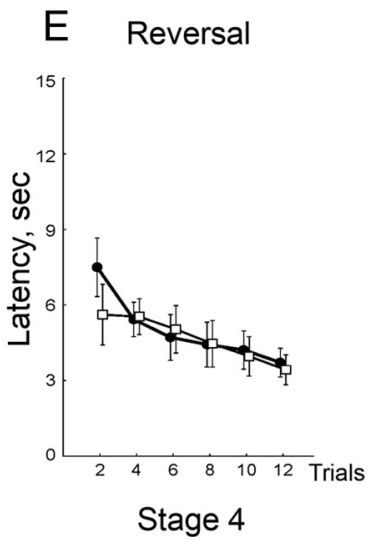

Figure 1. Preserved right-left discrimination and egocentric reversal learning in APPsi:tTA mice. $A$, Consecutive stages of training in a Plus water maze task with examples of correct paths for each stage. $\boldsymbol{B}-\boldsymbol{E}$, Latencies to reach the hidden platform for NTg control $(n=14)$ and APPsi:tTA mice $(n=13)$ are shown for a straight swim $(\boldsymbol{B})$, left turn $(\boldsymbol{C})$, free choice $(\boldsymbol{D})$, and reversal $(\boldsymbol{E})$ stages. There were no significant effects of genotype at any stage of the testing $(p \geq 0.45)$., control NTg mice; $\square$, APPsi:TA mice.

driven by the expression of mutant APP under the transcriptional control of a tetracycline regulated promoter (Jankowsky et al., 2005). In the initial description of this model, we reported that these animals develop a robust amyloid pathology and that these deposits persist long after expression of mutant APP is suppressed by exposure to doxycycline (DOX) (Jankowsky et al., 2005). In this report, we sought to determine the cognitive phenotypes of this model, finding that 12- to 13-month-old APPsi: tTA mice that have relatively high amyloid burden show impairments in both short- and long-term memory tasks. Using immunological and biochemical approaches, we further assessed which pathologic features of this model persist when the expression of mutant APP is suppressed.

\section{Materials and Methods}

Animals. The mouse model of inducible amyloidosis is based on tetracycline-regulated vectors that express a chimeric mouse/human APP with the Swedish and Indiana mutations of familial AD, Line 107 (Jankowsky et al., 2005). Expression of the mutant APP requires coexpression of the tetracycline-Transactivator (tTA), which is under the transcriptional control of the CaMKII $\alpha$ promoter, so that the mice studied are bigenic APPswe/ind $\times$ tTA (abbreviated APPsi:tTA mice). Both of the transgenes have been crossed into the C57BL/6J strain of mice for at least 10 generations to create congenic transgenic animals. Mice for behavioral testing were bred by crossing APPsi:tTA (Line 107) males on a congenic C57BL/6J background to nontransgenic (NTg) FVN female mice to yield F1 progeny. Breeding cages were fed DOX diet (200 $\mu \mathrm{g}$ of DOX per gram; Bioserve) and then at weaning on postnatal day 28 the weanlings were switched to a regular diet and maintained on such until noted in the text. All mice had free access to food and were housed in automatically controlled light conditions (light 7:00 A.M. to 9:00 P.M.). All procedures were conducted according to the National Institutes of Health guide for animal care and approved by the University of Florida and Johns Hopkins University Institutional Animal Care and Use Committees. Only male mice were used for behavioral testing. The same animals were used in three cognitive tasks described below (longitudinal design). For analysis of APP, APP proteolytic derivatives, and A $\beta$ levels, both male and female mice were used.

Acclimation to behavioral testing. Mice were handled 3 times, $5 \mathrm{~min}$ each, before the start of each session of behavioral testing. All testing was conducted during the light phase of the circadian cycle in cohorts of 8-10 mice, balanced by genotype. Before each test, mice were moved to the testing room and allowed to habituate to the new location for at least $1 \mathrm{~h}$ before behavioral testing.

Left-right discrimination and mirror-reversal in a Plus water maze. The control NTg male mice $(n=13)$ and their APPsi:tTA littermate $(n=14)$ male mice were trained in a low-demand Plus water maze task to assess the swimming abilities and basic learning capacity at 10-12 months of age. The Plus water maze was made from a clear acrylic material (each arm $15 \mathrm{~cm}$ wide and $38 \mathrm{~cm}$ long), placed inside a circular pool, and surrounded by a set of spatial cues. A hidden platform $(10 \times 10 \mathrm{~cm})$ was placed at the end of one of the arms and submerged $1 \mathrm{~cm}$ under the surface of opaque water (water temperature $22 \pm 1^{\circ} \mathrm{C}$ ). The paradigm included four consecutive stages (Fig. 1A). Stage 1: First, the mice were trained to find the hidden platform located at the end of a start arm of the Plus water maze (a straight swim test, 4 trials). Stage 2: The left arm of the maze was opened and the platform was moved to the end of this arm for another 4 trials. Stage 3: After a $24 \mathrm{~h}$ delay, an additional, right arm of the maze was opened with the platform remaining in the left arm and the animals were tested for retention of spatial memory for the platform location ( 12 trials). To ensure that all animals were aware of the new arm, the first trial was conducted with start position at the end of the new arm. The start position for the rest of the trials was located at the end of the original start arm. Stage 4: A reversal stage was introduced $24 \mathrm{~h}$ later in which the start arm was moved to create a symmetrical mirror-reflected start position, and mice were required to turn right to find the platform, which was surrounded by the same spatial cues used in previous sessions. 
A

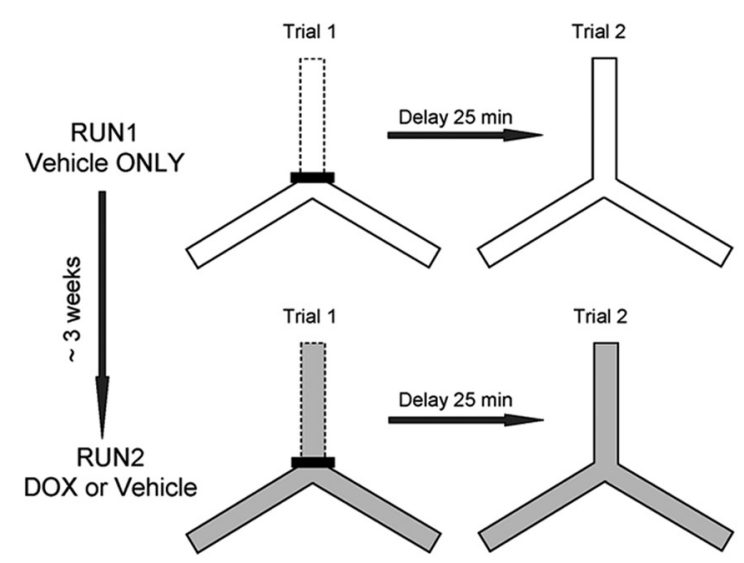

C

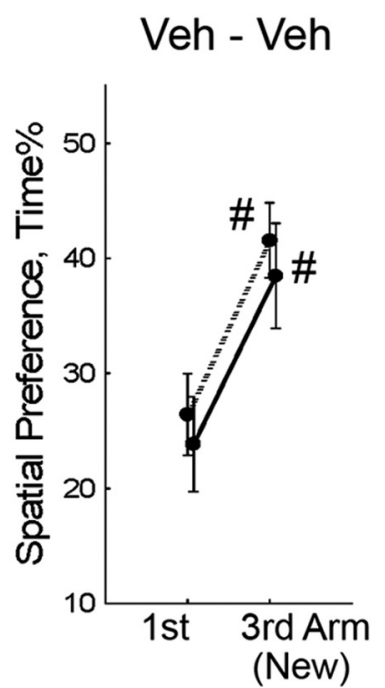

B

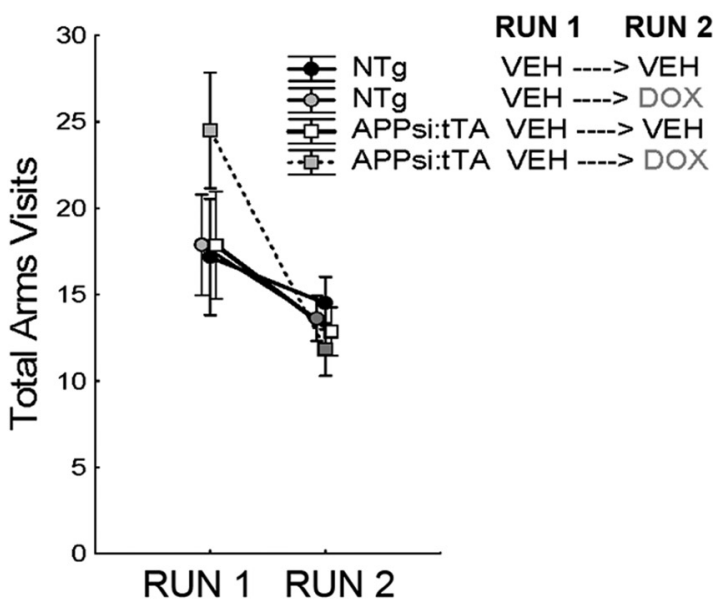

D APPsi:tTA mice

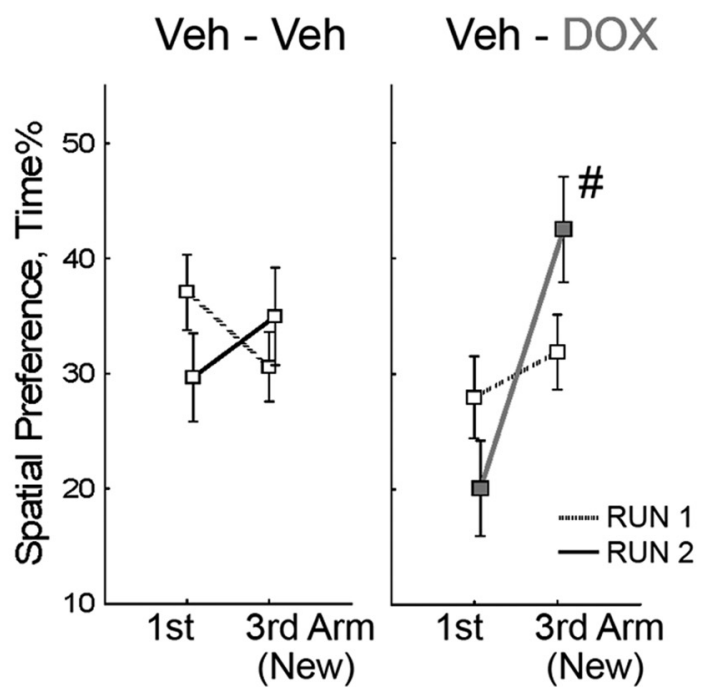

Figure 2. Reversal of deficits in short-term spatial recognition memory. $\boldsymbol{A}$, Scheme for testing in a two trial $Y$ maze task. $\boldsymbol{B}$, Motor activities during testing are shown as the total number of arms visited during first and second runs of the task. Two-way Group $\times$ Runs ANOVA revealed significant effects only in Runs $\left(F_{(1,23)}=12.39, p=0.0018\right)$, indicating that motor activities of the APPsi:tTA mice were similar to that of NTg littermates (effect of Group, $F_{(3,23)}=0.50, p=0.686$ ) in both runs of the task (Group $\times$ Run interaction, $p=0.241$ ). C, D, Spatial preferences to different arms of the $Y$ maze are shown as percentage of time spent in the new and one of the old arms. C, Left Veh-Veh panel, Spatial preferences of the NTg mice $(n=6)$ that received regular diet during the first (dotted line) and second (solid line) runs of the task. Two-way Arms $\times$ Run ANOVA yielded significant preference to the new Arm (effect of Arm, $\left.F_{(1,5)}=20.66, p=0.006\right)$ in both runs of the task (effect of Run, $F_{(1,5)}=2.36, p=0.185$; Arms $\times$ Run interaction, $\left.p=0.926\right)$. Right Veh-DOX panel, Performances of the NTg mice $(n=8)$ that were switched to a D0X diet $7 \mathrm{~d}$ before the second run of the task. Their preferences to the new arm (ANOVA, effect of Arms, $F_{(1,7)}=30.96, p=0.0009$ ) were not significantly affected by DOX (effect of Run, $F_{(1,7)}=0.39, p=0.553 ;$ interaction, $p=$ 0.253). $D$, The APPsi:tTA mice on vehicle diet (left Veh-Veh, $n=7$ ) showed no preferences to the new arm (ANOVA, effect of Arm, $F_{(1,6)}=0.01, p=0.941$ ) in any run of the task (effect of Run, $F_{(1,6)}=0.15, p=0.714$; interaction, $p=0.296$ ). In contrast, the APPsi:tTA mice that were switched to DOX diet 1 week before testing (right Veh-DOX, $n=6$ ) significantly preferred the new arm in the second run of the test (ANOVA, effects of Arms, $F_{(1,5)}=53.37, p=0.0008 ;$ Run, $F_{(1,5)}=0.13, p=0.734$; and Arms $\times$ Run interaction, $p=0.032$ ). $\boldsymbol{C}, \boldsymbol{D}$, , ${ }^{\#}$ Significant preference to the new arm of the maze ( $p \leq 0.01$, Fischer LSD post hoc test).

In all stages of training in the Plus water maze, the maximum duration of each trial was $60 \mathrm{~s}$. The mice were allowed to stay on the platform for $10 \mathrm{~s}$ after finding the platform. If mice did not find the platform, they were gently guided to the platform. If a mouse jumped from the platform, the experimenter pointed to the platform and waited until the mouse returned to the platform. Jumping from the platform was observed in both genotypes only during the first stage of the training. In general, taking mice to their waiting cage only if they stay on the platform quickly extinguishes jumping behavior. After removing the mice from the platform, they were dried with paper towels and placed in a dry waiting cage for 25-min-long inter-trial intervals. Consecutive choices of the arms of the maze and latency to find the platform were recorded by trained observers blind to genotypes.
Spatial recognition memory in a two trial $Y$ maze. After the initial round of testing in the Plus water maze, the animals were returned to the general housing area before further behavioral testing started when they reached 12.5 months of age. The two trial Y maze task was conducted as described previously (Melnikova et al., 2006), consisting of 2 trials separated by an interval of $25 \mathrm{~min}$ to assess short-term spatial memory. After the first run of the task, the mice were returned to the housing facility for 2 weeks before initiating DOX diet for one additional week (Fig. 2A). For the two runs of the task, two geometrically identical $Y$ mazes were used with each arm of the two mazes measuring $48 \times 7 \mathrm{~cm}$ and with 2 - $\mathrm{cm}$-high borders. The mazes were differently colored, made of different material (metal vs wood), placed in different rooms, with different spatial cues, and cleaned by different solutions ( $30 \%$ ethanol or $5 \%$ orange soap). During trial 1 of 
A Reference Memory Day 1

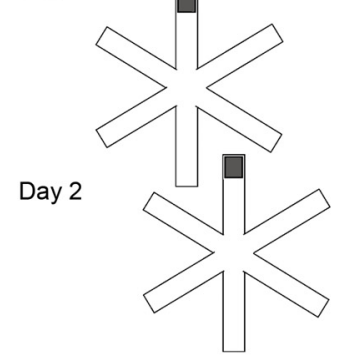

Working Memory

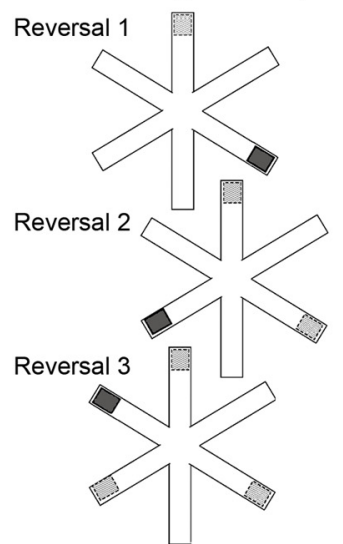

B

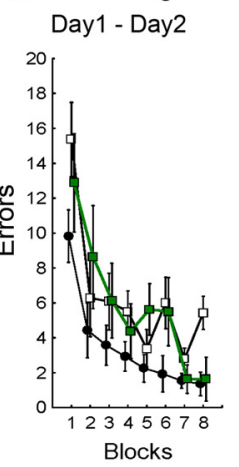

F Total Errors in Reversals

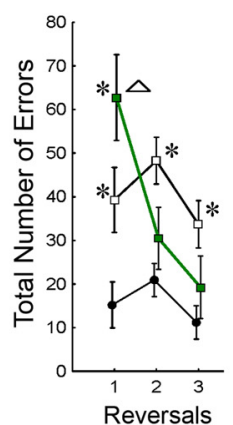

C Errors in the last Block
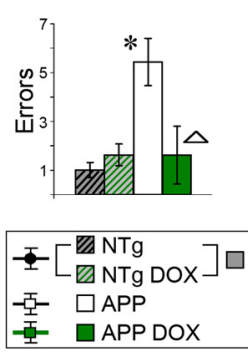

G Working Memory Errors

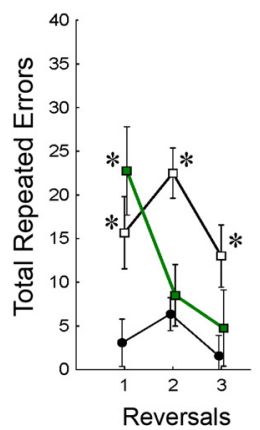

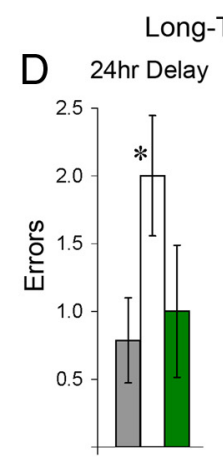

$\mathrm{H}$ Errors due to Reference
Memory

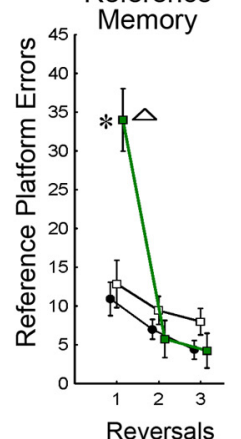

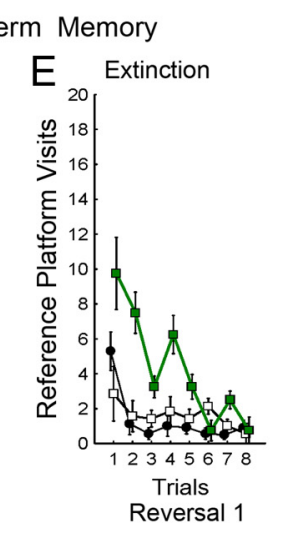

I Errors due to all Previous

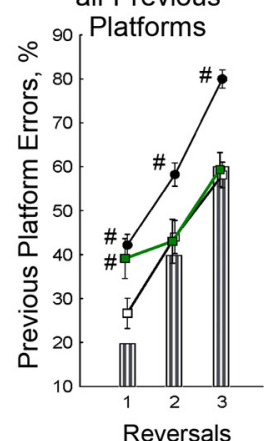

Figure 3. Partial rescue of deficits in long-term reference memory and working memory. $A$, Top, Diagram of the locations of the hidden escape platform ( $\square$ ) in the RAWM. Bottom, Diagram of the locations of platform as it was moved in consecutive days of testing (dark box). $\boldsymbol{B}$, Average number of errors per trial is shown for blocks of 2 trials across $2 \mathrm{~d}$ of training. Number of errors to find the arm that originally contained the escape platform decreased in all groups of mice (NTg, $n=13 ;$ Off-DOXAPPsi:TA, $n=7 ; 0 n$-DOXAPPsi:tTA, $n=5)$ (two-way group $\times$ block ANOVA, significant effect of block, $F_{(7,154)}=15.71, p=1.9 \times 10^{-15}$; and group, $\left.F_{(2,22)}=7.64, p=0.003\right)$.C, Average number of errors in the last block of trials. The APPsi:TTA mice On-DOX diet showed a low number of errors similar to that in control groups, whereas the APPsi:TTA mice on regular diet made significantly more errors than other groups (two-way genotype $\times$ diet ANOVA, significant effect of genotype, $F_{(1,21)}=4.35, p=0.048$; and genotype $\times$ diet interaction, $\left.F_{(1,21)}=4.45, p=0.049\right)$. ${ }^{*} p=0.005$, difference from controls (LSD post hoc test). ${ }^{\triangle} p=0.028$, difference from 0ff-D0X APPsi:TTA (LSD post hoc test). D, Long-term memory for the platform location was assessed after a $24 \mathrm{~h}$ delay and shown as the average number of errors before finding the location of the arm containing the escape platform. The Off-DOX APPsi:tTA group made more errors than controls ( ${ }^{*} p=0.045, t$ test, $t=2.147$ ), whereas performance of the 0n-DOX APPsi:tTA group was not different from controls. $\boldsymbol{E}$, The extinction of reference memory is shown for the first day of reversal training. The 0n-DOXAPPsi:tTA mice made significantly more visits to the location of the reference platform than controls (two-way group $\times$ trial ANOVA, effect of group, $F_{(2,22)}=13.12, p=0.0002$ ) but decreased these visits by the end of the session (effect of trial, $F_{(7,154)}=14.20, p=3.7 \times 10^{-14}$; and group $\times$ trial interaction, $\left.F_{(14,154)}=3.42, p=0.00008\right)$. $F$, Total number of errors accumulated during three consecutive reversals is shown. Two-way group $\times$ session ANOVA yielded significant effect of group $\left(F_{(2,22)}=23.97, p=3.0 \times 10^{-6}\right)$, session $\left(F_{(2,44)}=5.43, p=0.008\right)$, and interaction $\left(F_{(4,44)}=2.99, p=0.029\right)$. The Off-DOX APPsi:tTA mice made significantly more errors than controls in all reversals ( ${ }^{*} p \leq 0.004$, LSD post hoc test). The On-DOX APPsi:tTA mice performed significantly worse than controls $\left({ }^{*} p=2.6 \times 10^{-6}\right.$, LSD post hoc test) and Off-DOX APPsi:tTA group ( $\mathbf{\Delta}_{p}=0.025$ ) only in the first reversal session. G, Working memory errors are shown as the total number of repeated errors. Two-way group $\times$ session ANOVA yielded a significant effect of group $\left(F_{(2,22)}=22.94, p=5.2 \times 10^{-6}\right)$, session $\left(F_{(2,44)}=4.91, p=0.012\right)$, and interaction $\left(F_{(4,44)}=3.00, p=0.029\right) .{ }^{*} p \leq 0.006$, difference from controls (LSD post hoc test). $\boldsymbol{H}$, Extinction of visits to the arm that originally contained the escape platform in the course of reversal sessions. In the first reversal session, the On-DOX APPsi:tTA mice made significantly more errors than mice Off-DOX or NTg mice. Two-way group $\times$ session ANOVA yielded an effect of group $(F=9.65, p=0.001)$, session $\left(F=26.17, p=3 \times 10^{-8}\right)$, and interaction $(F=7.98, p=0.00006)$. ${ }^{*} p=4.8 \times 10^{-9}$, difference from controls (LSD posthoc test). $\mathbf{\Delta}_{p}=4.6 \times 10^{-7}$, difference from Off-DOXAPPsi:TTA (LSD post hoc test).I, Percentage of errors made as a result of visits to previous platform locations. The level of chance performance (shown by striped columns) increases with successive reversals (see scheme in $A$ ). " $S$ Significant differences from chance level with the $p$ level corrected for a number of comparisons $(p<0.0056)$. Two-way group $\times$ session ANOVA revealed significant effect of group $(F=17.87, p=0.00002)$, session $\left(F=78.51, p=3.0 \times 10^{-15}\right)$, and interaction $(F=2.74, p=0.040)$.

each run (Fig. 2A), one of the arms of the maze was blocked, allowing exploration of only two arms of the maze. After a 25 min delay, trial 2 was conducted in which all three arms were available for exploration. Trial 2 takes advantage of the innate tendency of mice to explore novel areas (Ennaceur and Delacour, 1988), and mice with intact spatial recognition memory will prefer to explore a novel arm over familiar arms, whereas mice with impaired spatial memory will enter all arms equally (Conrad et al., 1996). Thus, trial 2 represented a classic test for spatial recognition memory as described by Dellu et al. (1997). Motor activity was recorded as number of arms visited for a whole duration of the trials ( 5 min each). Behavior was scored by trained observers blind to genotype using a computer-assisted data acquisition system (Stopwatch+; http://www.cbn-atl.org/research/stopwatch.shtml).

Spatial reference and working memory in the radial water maze. The radial water maze task was conducted as described previously (Arendash et al., 2001; Laird et al., 2005; Savonenko et al., 2005) with minor modifications. Because all mice were familiarized to the procedural aspects of the task (an existence of hidden escape platform) during testing in the Plus water maze task, no further pretraining was required. A radial maze enclosure was placed in a large diameter pool $(100 \mathrm{~cm})$, filled with opaque water $\left(21 \pm 2^{\circ} \mathrm{C}\right)$ that was surrounded by a new set of distal and proximal spatial cues. The enclosure was made of clear plastic with a $2 \mathrm{~cm}$ yellow line painted at the level of the water for easier detection of the radial maze walls by the mouse. The platform was kept in the same location for the first two training days and then changed between different arms daily for the rest of the testing (Fig. $3 A$ ). The start position was located at the end of an "unbaited" arm and randomly changed every trial. Eight daily trials were conducted in which the mice were allowed to swim freely between arms to find the platform with the maximum duration of each trial $120 \mathrm{~s}$. Ten seconds after finding the platform, the mice 
were removed from the platform, dried with a paper towel, and placed in a dry waiting cage for $25 \mathrm{~min}$ before the next trial. Two APPsi:tTA mice (one, On-DOX; and one, on regular diet) were excluded from the analyses because of their inability to choose an arm and persistent swimming in the center of the maze. Performance in the radial water maze was recorded by the HVS Image Analysis VP-200 tracking system (HVS Image). An experimenter, unaware of the mouse genotype, recorded the sequence of arm entries by viewing the video monitor. The number of errors was determined as a number of entries (full body length) into the arms before finding the platform.

Antibodies. In immunoblots, we used three anti-A $\beta$ monoclonal antibodies that have been previously demonstrated to recognize the $\mathrm{A} \beta$ sequence of APP: mAb 4G8 (Covance), which recognizes amino acid residues $17-24$ of both human and mouse $A \beta ; \mathrm{mAb} 6 \mathrm{E} 10$ (Covance), which preferentially recognizes an epitope within amino acids 3-8 of human $\mathrm{A} \beta$ (Kim et al., 1990); and anti-human $\mathrm{A} \beta$ (N) 82E1 antibody (IBL America), which recognizes the extreme $\mathrm{N}$ terminus of human $\mathrm{A} \beta$ peptide. We also tested a number of additional antibodies, including the following; anti- $\beta$ amyloid (\#2454; Cell Signaling), which recognized aggregated $A \beta$ at the top of gel in immunoblots (data not shown) and anti- $\beta$ amyloid (AB1510; Millipore), with weak specificity on immunoblots (data not shown). Antibodies to APP included 22C11, which recognizes an epitope near the $\mathrm{N}$ terminus of mouse and human APP; CT-20 (Pinnix et al., 2001), which recognizes the C-terminal 20 amino acids of mouse and human APP; and an anti-APP C terminus antibody (Millipore). The secreted ectodomain of APPsi was detected with antihuman sAPP $\beta$-Swe, 6A1 antibody (IBL America). In immunohistochemistry, we used monoclonal antibodies $6 \mathrm{E} 10$ and rabbit polyclonal antibody OC (EMD; Millipore) (Kayed et al., 2007), which recognize the human $\mathrm{A} \beta$ sequence and fibrillar $\mathrm{A} \beta$, respectively. For ELISA analysis, we used human anti-A $\beta_{42}$ (Rabbit Monoclonal Clone 1-11-3, Covance) and mAb 4G8.

Tissue harvest and brain fractionation. Two methods of tissue harvest and fractionation were used: With Method 1, for mice that were harvested after behavioral testing, the mice were intracardially perfused with cold PBS under deep anesthesia, the brains were removed and cut sagittally. The left brain hemisphere was fixed by immersion in $4 \%$ paraformaldehyde for immunohistochemistry. The second hemisphere was dissected to obtain the cortex and hippocampus, which were snap frozen on dry ice and stored at $-80^{\circ} \mathrm{C}$ until further biochemical analysis. For immunoblot analyses, the frozen cortex samples were sonicated in 10 volumes of ice-cold PBS containing protease inhibitors (Roche Diagnostics). For preparation of cytosolic and membrane fractions, $200 \mu \mathrm{l}$ of cortex homogenate was centrifuged at $100,000 \times g$ for $60 \mathrm{~min}$ at $4^{\circ} \mathrm{C}$. The supernatant was collected and served as the cytosolic fraction (S1); this fraction was analyzed for detection of different types of soluble APP in immunoblot analyses. The membrane pellet (P1) was solubilized by sonication in 10 volumes of radioimmunoprecipitation assay buffer (RIPA) containing $1 \%(\mathrm{w} / \mathrm{v})$ SDS and protease inhibitors, and insoluble material was removed by centrifugation at $14,000 \times g$ for $10 \mathrm{~min}$ at $4^{\circ} \mathrm{C}$. Crude membrane fraction was used for detection of full-length APP, C-terminal fragments (CTFs), and $\mathrm{A} \beta$ species. Protein concentrations were determined by using the BCA Protein Assay Kit. The proteins were separated on NuPAGE Bis-Tris 4-12\% gradient gels in MES-SDS running buffer and transferred to nitrocellulose membranes by using iBlot Dry Transfer System (Invitrogen). The cytosolic (S1) and crude membrane (P1) fractions were analyzed by immunoblotting with $\mathrm{mAb} 6 \mathrm{E} 10$ antibody, antihuman sAPP $\beta$-Swe, $6 \mathrm{Al}$ antibody, anti-APP, C terminus antibody, and anti-human amyloid $\beta(\mathrm{N})$ 82E1 antibody.

With Method 2, a more extensive fractionation protocol was also used to identify soluble and insoluble derivatives of APP. In this protocol, we strived to avoid freezing tissues and thus limit the introduction of freeze/ thaw artifacts. After perfusion with chilled PBS, pH 7.5, the brains were harvested and chilled for $\sim 15 \mathrm{~min}$, then sectioned into $1 \mathrm{~mm}$ pieces on a cutting block/sectioning device. Each section containing forebrain was placed on a glass slide on ice and diced into smaller pieces with a razor blade. The diced pieces were placed in a $1.7 \mathrm{ml}$ of microfuge tube and gently washed with $1 \mathrm{ml}$ of $1 \times \mathrm{PBS}$ with protease inhibitor mixture (Sigma-Aldrich) and then centrifuged at $3000 \times g$ for $1 \mathrm{~min}$ in a $4^{\circ} \mathrm{C}$ microfuge. The supernatant was poured off carefully before resuspension in $1 \mathrm{ml}$ of $1 \times$ PBS containing protease inhibitor mixture by gently "stirring" brain pieces and repeating the centrifugation. After the supernatant was gently poured off, the pieces were resuspended in $500 \mu \mathrm{l}$ of $\mathrm{dH}_{2} \mathrm{O}$ containing protease inhibitor mixture in a microfuge tube by gently "stirring" the brain pieces, and then kept on ice. After $1 \mathrm{~h}$, the tubes were centrifuged at $12,000 \times \mathrm{g}$ for $10 \mathrm{~min}$ in a $4^{\circ} \mathrm{C}$ microfuge, and the supernatant was placed in a new tube (water-extractable). A portion (15 $\mu \mathrm{l}$ ) was immediately analyzed by SDS-PAGE and immunoblotting. The pellet fractions were resuspended in water by gentle pipette trituration and then held on ice for an additional hour before centrifugation at $12,000 \times g$ for $10 \mathrm{~min}$ in a $4^{\circ} \mathrm{C}$ microfuge. The supernatant was saved but not analyzed extensively as immunoblots of this fraction with 4G8 antibody were identical to immunoblots of the first water-extractable fraction (data not shown), and the pellet was resuspended in $500 \mu \mathrm{l}$ of $1 \times$ PBS by sonication ( 3 times for $10 \mathrm{~s}$ set at 2; Misonix) and then aliquoted and stored at $-80^{\circ} \mathrm{C}$.

To analyze protein that remained tissue associated, the frozen aliquots of homogenized tissue, which were in PBS, were thawed and then sonicated again (3 times for $10 \mathrm{~s}$ set at a setting of 2 ) and then centrifuged in an Airfuge (Beckman Coulter) at maximum speed $(\sim 150,000 \times g)$ for $10 \mathrm{~min}$. The supernatant was removed and saved as the PBS-soluble fraction and the pellet (PBS-insoluble fraction) was resuspended in $500 \mu \mathrm{l}$ of $1 \times$ PBS.

For all fractions, $15 \mu \mathrm{l}$ of sample was mixed with $5 \mu \mathrm{l}$ of $4 \times$ Laemmli buffer with $\beta$-mercaptoethanol and analyzed by SDS-PAGE. Samples were either boiled or electrophoresed without boiling as noted in the text and figure legends. Antibodies used for immunoblots are noted in the figure legends.

Neuropathology-thioflavin S staining and immunostaining. As noted above, mice that were behaviorally characterized were deeply anesthetized before transcardial perfusion with cold PBS to remove blood. The brains were removed and cut sagittally with one-half immersion fixed in $4 \%$ paraformaldehyde in PBS for $48 \mathrm{~h}$ at $4^{\circ} \mathrm{C}$. Additional mice that were analyzed neuropathologically without prior behavioral testing were prepared in essentially the same manner. After fixation, brains were washed in PBS and cryoprotected in 30\% sucrose in PBS for several days before cryostat sectioning at $30 \mu \mathrm{m}$ thickness. The sections were kept in antifreeze solution at $-20^{\circ} \mathrm{C}$ until staining. For thioflavin $\mathrm{S}$ staining, the sections were stained according to the Guntern standard protocol (Guntern et al., 1992). For immunostaining, free-floating sections were processed according to a standard protocol described in prior studies $\mathrm{Xu}$ et al., 2012). mAb 6E10 (1:1000, mouse monoclonal) and antibody OC ( $1: 1000$, rabbit polyclonal) were used to detect APP, $\mathrm{A} \beta$, and fibrillary $\mathrm{A} \beta$ assemblies. Secondary antibodies of goat anti-rabbit and goat antimouse, conjugated with Alexa-594 or Alexa-488 (Invitrogen) were used to visualize primary antibody binding.

ELISA. A $\beta$ peptide levels were quantified by sandwich ELISA. Plates were coated overnight at $4^{\circ} \mathrm{C}$ with human anti-A $\beta_{42}$ at a 1:1000 dilution in carbonate buffer (catalog \#C3041, Sigma-Aldrich). Plates were subsequently washed 3-4 times with PBS containing $0.05 \%$ Tween 20 (PBS-T) and allowed to block for at least $1 \mathrm{~h}$ in PBS-T containing 1\% BSA. After washing 3-4 times in PBS-T, $60 \mu \mathrm{l}$ of the water-extractable or PBSsoluble fractions was added directly to the plates; $\mathrm{P} 2$ fractions were first extracted in $70 \%$ formic acid, followed by neutralization in 20 -fold excess of $1 \mathrm{M}$ Tris base, $0.5 \mathrm{M} \mathrm{NaH}_{2} \mathrm{PO}_{4}$ before their addition to the plateau at a final overall dilution of 1:1000. For quantitation purposes, $\mathrm{A} \beta 42$ peptide standard curves were included on the plate ranging from 0 to $1000 \mathrm{pg} / \mathrm{ml}$. The ELISA plates were allowed to incubate at room temperature for at least $4 \mathrm{~h}$, at which time they were washed 3-4 times in PBS-T, and mouse monoclonal 4G8, $\beta$-amyloid 17-24, conjugated to HRP (Covance), was added at a dilution of 1:2000 in PBS-T containing $0.67 \%$ BSA and allowed to incubate for $45 \mathrm{~min}$. A $\beta$ peptides were detected using the Quantablu peroxidase substrate (Pierce) according to the manufacturer's specifications using a Molecular Devices FlexStation III plate reader. Concentrations of $\mathrm{A} \beta_{42}$ were calculated by interpolation of the corresponding standard curve.

Statistical analyses. The behavioral data were analyzed by factorial ANOVA with repeated measures wherever appropriate using the statistical package STATISTICA Version 8.0 (StatSoft) and the critical $\alpha$ level 
set to 0.05 . The independent factors were genotype (2 levels: NTg controls and APPsi:tTA mice), group (3 levels: a comparison between NTg controls and APPsi:tTA mice on DOX or regular diet), and diet (2 levels: on DOX or regular diet). The repeated measures were Runs, Arms (Y maze task), Trials, Block of trials and/or Sessions (reversals). A one-tailed $t$ test was applied to data of arm preferences (\%) to estimate the difference from a chance level (specified for the tasks in the text).

The data from ELISA measurements of $\mathrm{A} \beta 40$ and $\mathrm{A} \beta 42$ levels were analyzed using two-tailed $t$ test with the statistical tools in EXCEL.

\section{Results}

This study used an inducible model of Alzheimer-type amyloidosis (APPsi:tTA; see Materials and Methods) that rapidly develops high amyloid burden (Jankowsky et al., 2005). In the original description of these animals, which were maintained as hybrids of $\mathrm{C} 57 \mathrm{BL} / 6 \mathrm{~J}$ and $\mathrm{C} 3 \mathrm{H} / \mathrm{HeJ}$, the mice that were bigenic for APPsi and tTA were noted to show extreme hyperactivity (Jankowsky et al., 2005). In addition, when placed in a water maze, these mice displayed behavioral stereotypes (wall hugging) that made them difficult to test in this task. These phenotypes had rendered them virtually untestable in standard spatial memory tasks that assess cognition (Jankowsky et al., 2005). However, over time, we developed a breeding strategy that improved the baseline performance of bigenic APPsi:tTA mice in cognitive tests. In brief, we first bred the APPsi:tTA mice to C57BL/6J mice for 10 generations to generate $\mathrm{B} 6$ congenic animals. To produce mice for testing, we bred $\mathrm{B} 6$ congenic/bigenic male APPsi:tTA mice that had been maintained On-DOX throughout life to FVB/NJ female mice maintained On-DOX to produce isogenic F1 offspring. At weaning, we switched these F1 offspring to regular food, genotyped them, and then aged them out for behavioral studies. A similar strategy for breeding APPsi:tTA mice was independently developed by Rodgers et al. (2012) in the laboratory of Dr. Joanna Jankowsky, and this group has recently reported that APPsi:tTA mice bred in this manner show diminished hyperactivity phenotypes. The Jankowsky laboratory also demonstrated that F1 hybrids of $\mathrm{C} 57 \mathrm{BL} / 6 \mathrm{~J}$ and $\mathrm{FVB} / \mathrm{N}$ expressing tTA perform well in various memory tasks and rearing of these mice On-DOX protects them from tTA-induced neurodegeneration (Han et al., 2012). F1 hybrids of C57BL/6J and FVB/NJ mice have also been used in studies of mice that constitutively express WT and mutant APP and have been well characterized as a strain that show good learning capability and are not prone to develop visual defects that would interfere with spatial memory tasks (Moechars et al., 1999). We have also extensively tested visual discrimination in different cohorts of our APPsi:tTA model on the B6/FVB F1 background, and the data consistently show that these mice and their control littermates do not have visual deficits (data not shown). Although it is common practice in the literature for investigators to use both male and female APP transgenic mice in behavioral testing, in our hands, female mice have a tendency to show high variability in performance in spatial memory tasks. For this reason, all of the behavioral work described here has focused on only male mice.

\section{Preliminary assessments of testability in a Plus water maze} Behavioral testing of F1 APPsi:tTA mice began at 10-12 months of age and started with cohorts of 13 control NTg male mice and 14 APPsi:tTA littermate male mice. To familiarize the mice with the procedures of cognitive testing, we trained all mice to find a platform hidden under opaque water at the end of a straight arm using a Plus water maze apparatus (Fig. 1A). In this analog of a straight swim test (Savonenko et al., 2003), APPsi:tTA mice were successful in finding the platform without any competing responses (such as wall hugging, circular swimming) and performed similar to NTg littermates (Fig. 1B). Next, the mice were trained to turn left to find the hidden platform (Fig. 1A, Left Turn); and again, APPsi:tTA and control mice were indistinguishable in performance (Fig. 1C). After a $24 \mathrm{~h}$ delay, a third arm of the maze was opened to offer a free "left-versus-right" choice (Fig. 1A, Free Choice). In the first orientation trial, the mice were introduced into the maze at the end of the new arm to ensure that the mice were aware of a spatial novelty and then subsequently introduced at the original start site. Both APPsi:tTA and control mice required $\sim 4$ trials to reach criteria of 3 consecutive correct choices $(4.3 \pm 1.2$ and $4.1 \pm 1.1$ for APPsi:tTA and NTg mice, respectively). After reaching this criteria, the rate of errors in the subsequent trials remained low and similar between genotypes ( $4.9 \pm 2.8 \%$ and $3.7 \pm 2.7 \%$ for APPsi:tTA and NTg mice, respectively). In addition, the latency to find the platform was not significantly different between APPsi:tTA and NTg mice (Fig. $1 D)$. In the last phase of training the orientation of the Plus water maze was reversed $180^{\circ}$ (Fig. $1 A$, last panel) and the mice were tested to locate the escape platform, which was still surrounded by the same extra-maze cues, but in a position that required the mice to turn right instead of left. Both APPsi:tTA and NTg mice were able to adjust to the new location similarly (Fig. 1E). These data indicate that the swimming abilities of APPsi:tTA mice and their basic learning skills were largely indistinguishable from those of age-matched control mice. Of note, we observed that most of the mice of both genotypes used an egocentric, bodyoriented (Cook and Kesner, 1988; Packard and McGaugh, 1996; Chang and Gold, 2003), strategy to locate the escape platform as judged by their preference to turn "left" during the first trial of reversal training. The dominance of this strategy was not unexpected because the constant position of the start and escape platform in the previous training trials reinforced this behavior. All further tests of the APPsi:tTA mice used cognitive tasks that reinforce the use of allocentric, spatial cues, strategy to locate the escape platform.

\section{Short-term spatial recognition memory deficits in APPsi:tTA mice do not persist after suppression of new APPsi synthesis} To assess short-term spatial memory, we used a relatively low demand task called a two trial Y maze (Fig. 2A) (Dellu et al., 1997; Melnikova et al., 2006). For these studies, we staggered testing so that all animals were 12.5 months of age at the start of training. The animals were first habituated to two arms of the $\mathrm{Y}$ maze surrounded by a set of cues to help the animals orient. After a 25 min delay to assess short-term memory, the animals were reintroduced to the same Y maze and allowed to explore a third new arm. NTg controls showed significant preferences for exploring the new arm of the maze (Fig. 2C, Run 1), whereas APPsi:tTA did not (Fig. 2D, Run 1). This behavior was interpreted as evidence that the control mice had good short-term memory of exploring the old arms of the maze and thus explored the new arm preferentially, whereas the APPsi:tTA mice had poor short-term memory and did not recognize the novelty of the newly accessible third arm. The strong preference of the NTg mice for the novel arm also confirmed that the set of spatial cues we used in this task for orientation was sufficiently salient to enable the mice to discriminate the otherwise identical new and old arms.

After the first run of the Y maze task, both groups of mice, control and APPsi:tTA, were divided into 2 subgroups. After 2 weeks, one subgroup of animals was given DOX (On-DOX; to suppress APPsi expression) and the other was maintained Off- 
DOX. Both groups were then retested in the same task 1 week later. For this second run of the task, we used a second geometrically identical Y maze that differed from the one used in the first run in material, color, and cleaning solution and placed it in a different room with a different set of visible cues. For the NTg mice, either On- or Off-DOX, preference for a new arm was indistinguishable from that in the first run of the test (Fig. 2C, Veh-Veh $[n=6]$ and Veh-DOX [ $n=7]$ groups). Thus, testing of the NTg groups in the two trial Y maze revealed that measures of short-term spatial memory were not significantly affected by repeated testing or DOX diet. In contrast to NTg littermates, the APPsi:tTA mice that did not receive DOX $(n=8)$ showed persistent deficits in short-term spatial memory (Fig. 2D, Veh-Veh group). By contrast, the APPsi:tTA mice $(n=6)$ that received DOX showed a highly significant preference for the new arm of the maze (Fig. 2D, Veh-DOX group). The difference in behavior between the APPsi:tTA mice On- or Off-DOX was not associated with differences in overall motor activation because there were no significant differences in the number of arm entries across the two genotypes and treatment groups (Fig. $2 B$ ). Thus, we concluded that suppressing APPsi expression in the 12.5- to 13month-old APPsi:tTA mice rescued deficits in short-term spatial recognition memory.

\section{DOX-treated APPsi mice with improved short-term memory also display better performance in radial arm water maze tasks}

To further assess cognitive capabilities of APPsi:tTA mice OnDOX, we used the radial arm water maze (RAWM), which is a much more demanding spatial memory task compared with the two trial Y maze. In the RAWM, the mice were required to find a hidden escape platform in one of 6 arms of the maze by using spatial cues placed around the tank. In the first stage of training, we analyzed long-term spatial memory by using a paradigm in which the escape platform remained in a constant location over $2 \mathrm{~d}$ of testing (Fig. 3A). The NTg mice on regular diet $(n=6)$ or DOX diet $(n=7)$ steadily decreased the number of errors to find the platform as training progressed (ANOVA, effect of trial blocks, $\left.F_{(7,84)}=10.66 ; p=1.56 \times 10^{-9}\right)$ with no observable effect of DOX treatment on performance (ANOVA, effect of diet, $F_{(1,12)}=1.32, p=0.27$; block $\times$ diet interaction, $p=0.97$; also see Fig. $3 C$ ). For all analyses that follow, the data for the two NTg subgroups (On/Off DOX) were combined (Fig. 3B,D-I). The APPsi:tTA mice Off-DOX showed evidence of improved performance but made more errors than control NTg mice (Fig. $3 B$ ). APPsi:tTA mice On-DOX also improved performance with successive trials and by the last block of trials they were eventually performing at the level of NTg mice (Fig. 3C). To test long-term (reference) memory, we assessed the number of errors after a $24 \mathrm{~h}$ delay (Fig. $3 D$ ). During this probe trial, the APPsi:tTA mice Off-DOX performed at the level of chance with the number of errors being significantly higher than NTg controls $(t=2.147, p=0.045)$. For the APPsi:tTA mice On-DOX, the number of errors before locating the correct arm was equivalent to that in NTg controls $(t=0.35, p=$ 0.729; Fig. $3 \mathrm{D}$ ). These data provided the first indication that the cognitive improvements seen in short-term memory by APPsi:tTA mice On-DOX translated into sustained superior performance in the more demanding long-term memory task.

To assess the flexibility of memory traces, we used a paradigm in which the position of the escape platform was changed every day (Fig. $3 A$, lower diagram). In the first session after the platform was moved (Reversal 1), the APPsi:tTA mice On-DOX continued to visit the arm of the maze that originally contained the escape platform much more often than NTg control mice (Fig.
$3 E, H)$. This finding suggested that the APPsi:tTA mice On-DOX were not as cognitively flexible as the NTg controls. As a result of this deficit, the APPsi:tTA mice On-DOX showed a much higher error rate in the first reversal session than APPsi:tTA mice OffDOX (Fig. $3 F$ ). However, in subsequent sessions (Reversals 2 and 3 ), when the impact of errors resulting from visits to the first platform location was minimal (Fig. $3 H$ ), the APPsi:tTA mice On-DOX displayed an error rate that was similar to that of NTg controls (Fig. $3 F$ ). In particular, the APPsi:tTA mice On-DOX were not different from controls in the number of working memory errors assessed as total number of repeated entries to any arm in Reversals 2 and 3 (Fig. 3G). Even though the error rate of the APPsi:tTA mice On-DOX improved in the second and third reversal sessions, the mice did not display a preference for arms that had contained the escape platform in previous sessions (see $\mathrm{Re}$ versal 2 and 3, Fig. 3I). In contrast, NTg controls appeared to remember each of the previous platform positions in this task (so-called episodic-like memory) and visited the arms that had contained the escape platform in the previous sessions at a frequency higher than chance (Fig. 3I).

Collectively, these data indicated that suppressing new $\mathrm{APP} / \mathrm{A} \beta$ production in these middle-aged APPsi:tTA mice produced a rapid improvement in short-term spatial memory with a sustained superior performance in more demanding tasks of long-term reference memory. The only persistent cognitive impairment in the APPsi:tTA mice On-DOX was reduced cognitive flexibility and poorer episodic-like memory as evidenced by their performance in the reversals task of the RAWM.

\section{Persistent amyloid deposition}

After the last round of RAWM testing, which amounted to $\sim 3$ weeks after they were first given DOX, the animals were killed, and we assessed levels of amyloid deposition. As expected from prior studies of this model (Jankowsky et al., 2005), the brains of mice On-DOX still contained high levels of thioflavin-positive amyloid deposits (Fig. 4A); a notable limitation of the analyses of amyloid and APP levels in the brains of mice that have been through the full battery of behavioral studies was that we were not able to observe events that occurred within the $7 \mathrm{~d}$ time frame in which we observed rapid improvement in short-term spatial memory. We therefore undertook a more extensive analysis of APP and A $\beta$ levels in the brains of F1 APPsi:tTA mice that had been raised in a manner similar to behaviorally characterized animals. In this part of the study, we focused our effort on determining the relationships between deposited amyloid and soluble $\mathrm{A} \beta$ peptides entities. Thus for this work, we studied animals that had been aged somewhat longer than the mice used in behavioral studies to accumulate greater levels of $\mathrm{A} \beta$.

In our first set of pathologic studies of such mice, we immunostained sections from mice that were aged to 23 months and then placed on DOX for 7 d or 5 weeks with antibodies to APP/A $\beta$ $(\mathrm{mAb} 6 \mathrm{E} 10)$ and with antibodies specific to fibrillar $\mathrm{A} \beta$ (OC antibody) (Kayed et al., 2007). Mature amyloid deposits were recognized by both the $6 \mathrm{E} 10$ and $\mathrm{OC}$ antibodies, and this reactivity persisted out to 5 weeks as mice were continuously treated with DOX (Fig. 5). Within cells of the CA layer of the hippocampus, we detected 6E10 immunoreactivity in mice Off-DOX as well as mice that had received DOX for $7 \mathrm{~d}$ (Fig. $5 \mathrm{~A}, \mathrm{C}$ ). After 5 weeks On-DOX, the cellular 6E10 immunoreactivity had disappeared, but there was a persistent punctate cellular staining with the OC antibody (Fig. 5E,F). However, this punctate staining was also seen in age-matched NTg mice and when sections from NTg mice were stained with secondary antibody alone. Thus, we 
could not discern whether this cellular staining with OC antibody was some assembly of $\mathrm{A} \beta$ or an irrelevant reactivity. These data indicated that cellular reactivity to $\mathrm{mAb} 6 \mathrm{E} 10$ (which recognizes transgene-derived full-length APP, APP C-terminal fragments, and $\mathrm{A} \beta$ ) persisted for $\sim 7 \mathrm{~d}$ but then eventually cleared. The most persistent source of mAb 6E10 and OC antibody immunoreactivity was amyloid deposits.

\section{Analysis of APP soluble proteolytic derivatives in the brains of APPsi:tTA mice}

First, we analyzed brain homogenates from the animals that had been behaviorally tested. PBS-soluble fractions (S1) were compared with membrane fractions generated by solubilizing the PBSinsoluble fraction in modified RIPA buffer (P1) (see Materials and Methods). Each fraction was probed with mAb $6 \mathrm{E} 10$ (Fig. 6A,B). As expected, S1 fractions were free of membrane-associated protein, such as synaptophysin (data not shown). In the $\mathrm{S} 1$ fraction, a single band was observed that migrated at the position expected for secreted ectodomain $\operatorname{sAPP} \alpha$. This band was reduced in intensity in mice that received DOX diet through behavioral testing. In the $\mathrm{P} 1$ fractions, we similarly detected a band that migrated at the size expected for full-length APP as well as a band that migrated at the size expected for the $\beta$-CTF of APP and a strong band of monomeric $\mathrm{A} \beta$. In the

P1 fraction, additional immunoreactive bands were seen at multiple positions in the gel (Fig. 6B). Using an antibody specific for the ectodomain of APP generated by BACE1 cleavage of APP harboring the Swedish mutations ( $\beta \beta A P P s w e)$, this derivative of APP was detected only in the S1 fraction as expected. After DOX treatment through the course of behavioral testing, s $\beta$ APPswe levels fell below the level of detection (Fig. 6C). In parallel to the drop in sAPP $\alpha$ and s $\beta$ APPswe, the level of APP C-terminal fragments also fell in the brains of mice treated with DOX (Fig. 6D). Finally, probing S1 fractions with 82E1 antibody failed to detect any forms of $\mathrm{A} \beta$ in mice Off- or On-DOX (Fig. $6 E$ ). By contrast, in the P1 fractions, the $82 \mathrm{E} 1$ antibody detected multiple forms of immunoreactivity, including a band that migrated at the size expected for the $\beta$ CTF of APP (Fig. $6 F$ ). The identity of the other immunoreactive bands is uncertain; these could be various oligomeric assemblies of $\mathrm{A} \beta$. The $82 \mathrm{E} 1$ antibody does not recognize full-length APP or any sAPP ectodomains because of its specificity for the $\mathrm{N}$ terminus of $\mathrm{A} \beta$ (Horikoshi et al., 2004). Compared with APPsi:tTA mice Off-DOX, the levels of all APP derivatives, except monomeric $A \beta$, dropped significantly over the course of the behavioral testing as the mice were treated with DOX (Fig. 6G).

We next turned our attention to detecting and characterizing soluble forms of $\mathrm{A} \beta$ that are present before and after exposure to DOX for short (1 week) or longer (4 week) periods, using additional cohorts of APPsi:tTA mice. To obtain a fraction from brain that represented truly soluble and mobile $\mathrm{A} \beta$, we initially used a
NO DOX DOX
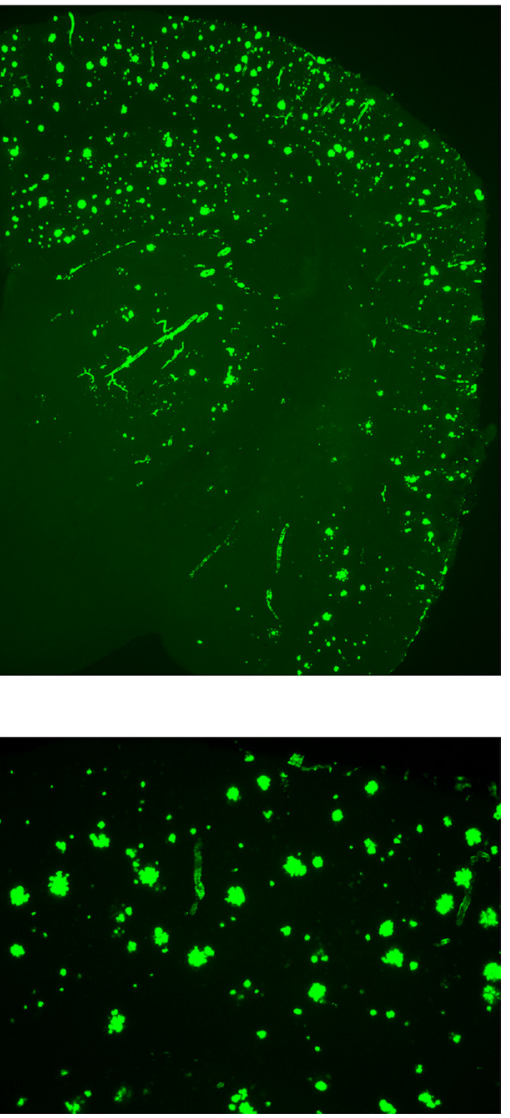

Figure 4. Persistence of thioflavin-positive amyloid plaques in APPsi:tTA mice. After the completion of all behavioral tasks, the mice were intracardially perfused with cold PBS under anesthesia, and half-brains were fixed by immersion in $4 \%$ paraformaldehyde. The $30 \mu \mathrm{m}$ frozen coronal sections through the cortex and hippocampus were stained with the amyloid-binding dye Thioflavin $S$. The images shown are representative of the entire cohort of animals that were behaviorally tested.

method that we thought would limit the potential to mechanically, or otherwise, create oligomers during the homogenization of the tissue. To gently elute soluble $\mathrm{A} \beta$ from the tissue, we dissected the brain and chilled it on ice for 10-20 min. We then diced the brain into small chunks that were $\sim 1 \mathrm{~mm}^{3}$ in size. The chunks were washed in cold PBS twice and then incubated on ice in distilled water for $1 \mathrm{~h}$ to osmotically elute soluble proteins from the interstitial space. These fractions, termed the waterextractable fractions, were immediately analyzed by SDS-PAGE and immunoblotting. Following this protocol, we observed that we could draw high levels of secreted APP ectodomains ( $\operatorname{APP} \alpha$ and/or $\mathrm{SAPP} \beta$ ) into the water-extractable fraction as detected with the 22C11 monoclonal antibody to N-terminal epitopes in APP (Fig. 7A). The 22C11 antibody is capable of recognizing full-length sAPP $\alpha$ and $\operatorname{sAPP} \beta$ derivatives of mouse and human APP (Fig. 7); however, the 22C11-positive band of APP immunoreactivity at $\sim 100 \mathrm{kDa}$ (Fig. $7 A$ ) was not recognized by an antibody to the C terminus of APP (Fig. $7 B$ ) and thus was identified as soluble APP ectodomains. The level of 22C11-reactive APP ectodomains fell in the brains of mice On-DOX for 4 weeks (Fig. 7A, compare lanes 1 and 2 with lanes 5-8) to levels comparable to mice transgenic for only tTA or APPsi (Fig. 7A, lanes 3-4). When we probed immunoblots of these same fractions with the $\mathrm{mAb} 6 \mathrm{E} 10$, which will recognize $\operatorname{sAPP} \alpha$ but not s $\beta$ APPswe, low levels of transgene-derived sAPP $\alpha$ were detected in APPsi:tTA mice OffDOX (Fig. 7C, lanes 1 and 2), but this derivative of APP disappeared 

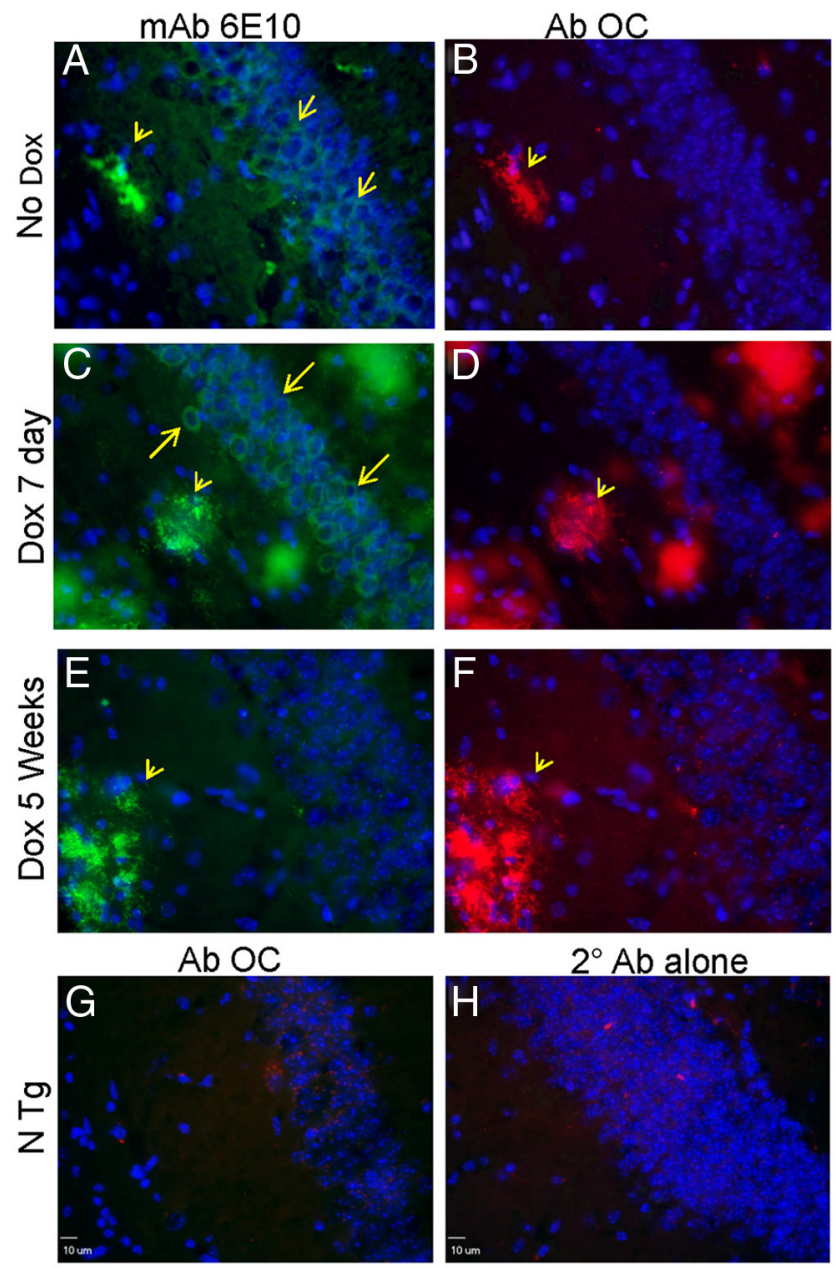

Figure 5. Rapid loss of $m A b 6 \mathrm{E} 10$ immunoreactivity with persistent 0 C antibody reactivity. $A$ separate cohort of APPsi:tTA mice with the same B6/FVB F1 genetic background were aged out to 22 months and then given DOX diet as noted on the figure. Cryopreserved frozen sections were immunostained with $\mathrm{mAb} 6 \mathrm{E} 10$ or the polyclonal $\mathrm{OC}$ as described in Materials and Methods. $A, C, E$, By 5 weeks after DOX treatment, cellular reactivity with mAb 6 E10 disappears (arrow), whereas amyloid plaque staining (arrowhead) persists. $\boldsymbol{B}, \boldsymbol{D}, \boldsymbol{F}$, The $\mathrm{OC}$ antibody preferentially recognizes amyloid deposits. We noted some punctate cellular reactivity of the $O C$ antibody in the CA layer of the hippocampus, but this staining was present in NTg mice $(\boldsymbol{G})$ and was also seen with secondary antibody alone $(\boldsymbol{H})$.

after 4 weeks On-DOX (Fig. 7C, lanes 5-8). Overall, these data indicated that this method successfully extracted the soluble ectodomains of APP from the tissues and that the levels of these soluble APP ectodomains derived from the APPsi transgene fell after synthesis of APPsi was inhibited by DOX treatment. Importantly, apart from the $\operatorname{sAPP} \alpha$ ectodomains that were detected in the water-soluble fraction by immunoblot with mAb 6E10 (Fig. 7C), there were no other bands that appeared to be specifically recognized and that could potentially represent a soluble oligomeric assembly of A $\beta$ in APPsi:tTA mice either Onor Off-DOX.

We then proceeded to examine the water-extractable fractions from APPsi:tTA mice that had been On-DOX for $7 \mathrm{~d}$. To preserve native structures as much as possible, samples were not boiled before SDS-PAGE. On each gel, we included samples of synthetic $\mathrm{A} \beta 42$ that contained oligomeric assemblies to serve as positive controls. Using synthetic $A \beta 42$ peptides and mAb 4G8, we estimated that we could detect oligomeric assemblies derived from 30 ng of $A \beta 42$ peptide by immunoblot (data not shown). When we probed immunoblots of the water-extractable fractions from the brains of 23-month-old APPsi:tTA mice that were either Offor On-DOX for $7 \mathrm{~d}$, we detected three bands of variable intensity (Fig. 7D). A $\sim 100 \mathrm{kDa}$ band that is of a size consistent with mouse or transgene-derived full-length APP was detected, but this band could not represent either of these species because the mAb 4G8 antibody does not recognize $\mathrm{APP} \alpha$ or s $\beta$ APPswe, and immunoblots of these water-extractable fractions with C-terminal antibodies to APP were negative (e.g., Fig. 7B), indicating that this band could not be full-length APP. We concluded that this band is likely to be a nonspecific band. Notably, the intensity of this band was highly variable across the sample set, which is often the case for nonspecific bands, and it was not more intense in the samples from APPsi:tTA mice Off-DOX compared with either NTg controls or APPsi:tTA mice On-DOX. Two additional bands of $\sim 25$ and $\sim 50 \mathrm{kDa}$ were also recognized by $\mathrm{mAb}$ $4 \mathrm{G} 8$ in these fractions; and again, the intensity of these bands varied across genotypes and were present in NTg and APPsi:tTA mice On-DOX at approximately equivalent levels (Fig. 7D). Thus, none of the bands recognized by mAb $4 \mathrm{G} 8$ in these blots could unequivocally be identified as oligomeric $A \beta 42$ in these water-extractable fractions. Based on the amount of sample we loaded on the SDS-PAGE gels, we estimate that we analyzed the equivalent of what could be extracted from $15 \mathrm{mg}$ of tissue. As noted above, we established that $4 \mathrm{G} 8$ could detect synthetic oligomeric $\mathrm{A} \beta$ formed from as little as $30 \mathrm{ng}$; thus, we can say that $15 \mathrm{mg}$ of tissue (assuming 100\% recovery) contained less oligomeric $\mathrm{A} \beta$ than the equivalent of assemblies formed by $30 \mathrm{ng}$ of the peptide.

We next turned to an analysis of proteins that could be solubilized by homogenization in PBS (see Materials and Methods). These PBS-soluble fractions were analyzed by immunoblot and were not boiled before electrophoresis (Fig. 8). In the PBSsoluble fractions from APPsi:tTA mice Off-DOX, immunoblots with $\mathrm{mAb} 6 \mathrm{E} 10$ detected a band of a size consistent with fulllength APP or sAPP $\alpha$ (Fig. 8B, lanes 2-5). This band was greatly diminished in APPsi:tTA mice On-DOX (Fig. 8B, lanes 6-9) and absent in NTg mice (Fig. $8 B$, lane 1). Notably, unlike the waterextractable fractions, probing the PBS-soluble fractions generated by homogenization revealed solubilized APP that could be recognized by the CT20 antibody (Fig. $8 C$ ), indicating that fulllength APP was present in this fraction. Importantly, by just $7 \mathrm{~d}$ On-DOX, all forms of PBS-solubilizable APP, which includes some full-length APP and any $\operatorname{sPP} \alpha$ not extracted into water, were greatly diminished. Additionally, in these PBS-soluble fractions, $\mathrm{mAb} 6 \mathrm{E} 10$ detected bands at 24 and $\sim 50 \mathrm{kDa}$ (asterisks) that were present at variable levels in all mice, including NTg mice, whether samples were boiled (data not shown) or not boiled before electrophoresis (Fig. 8B). Ultimately, we could not identify an immunoreactive band in PBS-soluble brain fractions from APPsi:tTA mice probed with mAb 6E10 that was completely specific to the transgenic mice, which was lost after DOX treatment, and was of a size consistent with oligomeric $\mathrm{A} \beta$.

\section{ELISA analysis of soluble and insoluble fractions from the brain of APPsi:tTA mice}

To determine whether the water-extractable or PBS-soluble fractions contained soluble $\mathrm{A} \beta 42$ peptides, we used an ELISA system that uses a C-terminal capture antibody with mAb 4G8 used as the detection antibody. Using synthetic $\mathrm{A} \beta 42$, we determined that this ELISA system does not detect oligomeric forms of $\mathrm{A} \beta$ (data not shown, no signal in ELISA assay). A $\beta$ was also undetectable in NTg mice by this ELISA. The levels of soluble, likely monomeric, $A \beta 42$ in water-extractable fractions of bigenic APPsi:tTA mice On-DOX for $7 \mathrm{~d}$ or 4 weeks were similar to that 
of mice Off-DOX (Fig. 9A, S1; average $\sim 0.8 \mathrm{ng} / \mathrm{ml}$ ). Similarly, the levels of PBSsoluble $\mathrm{A} \beta 42$ ranged $\sim 1 \mathrm{ng} / \mathrm{ml}$ in mice Off-DOX and the level did not fall significantly in mice On-DOX for $7 \mathrm{~d}$. This finding indicates that a fraction of $\mathrm{A} \beta 42$ in the brains of mice with high amyloid burden remains easily solubilizable for a protracted period after new APP synthesis has been inhibited. To quantify $\mathrm{A} \beta 42$ in the PBS-insoluble fractions, the insoluble material was dissolved in formic acid, neutralized, and then diluted for ELISA. As expected, the levels of $A \beta 42$ in the insoluble fractions of brains of mice OffDOX were thousands of times higher (range, $12-28 \mu \mathrm{g} / \mathrm{ml}$; with one outlier at $50 \mu \mathrm{g} / \mathrm{ml} ; n=6$ ) than what was detected in the soluble fractions and remained high in mice On-DOX for $7 \mathrm{~d}$ (range, 20-25 $\mu \mathrm{g} / \mathrm{ml} ; n=4)$. In an attempt to detect oligomeric $\mathrm{A} \beta$ by ELISA, we used an antibody directed against an N-terminal epitope to both capture and detect an $A \beta$ in the sample, a design similar to that of Xia et al. (2009). This system showed a sensitivity to detect synthetic oligomeric $\mathrm{A} \beta$ in solution that would be equivalent to $10 \mathrm{ng} / \mathrm{ml}$ A $\beta 42$; however, we failed to detect a signal in these water-extractable fractions from APPsi:tTA mice On- or Off-DOX (data not shown).

To compare the levels of $A \beta 42$ in different fractions, we used a volumetric method of normalization in which the volume of the water-extractable fraction, PBS-soluble, and resuspended PBSinsoluble fractions were equivalent. The minced brain fractions were prepared by incubating $500 \mathrm{mg}$ of diced tissue in 500 $\mu l$ of water; therefore, each microliter of the water-extractable fraction reflects what we could draw from $1 \mathrm{mg}$ of tissue. The PBS-soluble fractions were prepared by homogenizing the tissue after water extraction in $500 \mu \mathrm{l}$ of PBS and the PBSinsoluble fractions were finally resuspended in $500 \mu \mathrm{l}$ of buffer. Thus, for each fraction, the amount of $A \beta$ in $1 \mu$ l equated to $1 \mathrm{mg}$ of tissue. In water-extractable fractions of mice On- or Off-DOX, we detected $0.8-0.9$ pg of $A \beta 42$ per microliter. In PBS-soluble fractions, we detected 1-1.2 pg of $A \beta 42$ per microliter, whereas the levels of insoluble $A \beta 42$ in brain were $\sim 2500$ times higher at $25 \mathrm{ng}$ of $A \beta 42$ per microliter. Thus, only a minute fraction of total $A \beta 42$ that accumulates in the brains of these mice was easily leached out into water or solubilized by homogenization in PBS.

Immunoblot analysis of membrane associated fractions from the brain of APPsi:tTA mice

Last, we analyzed the PBS-insoluble fractions by SDS-PAGE by immunoblotting to characterize the membrane associated $A \beta$ in

G
A $6 \mathrm{E} 10$

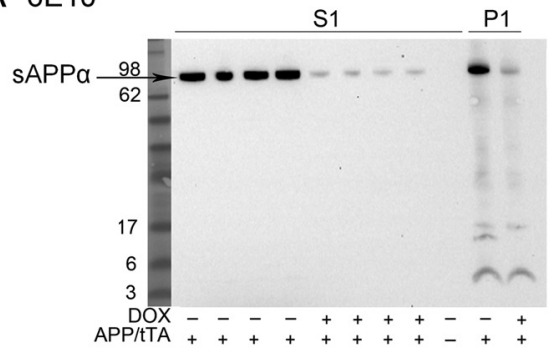

C $6 \mathrm{~A} 1$

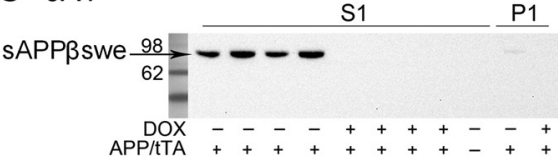

E $82 \mathrm{E} 1$

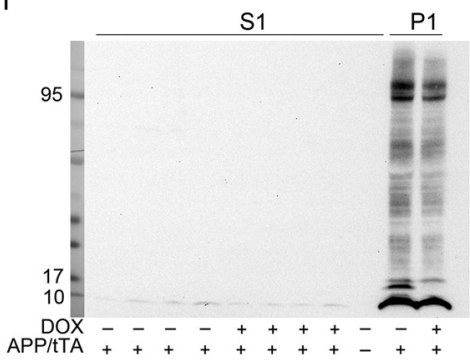

B $6 \mathrm{E} 10$

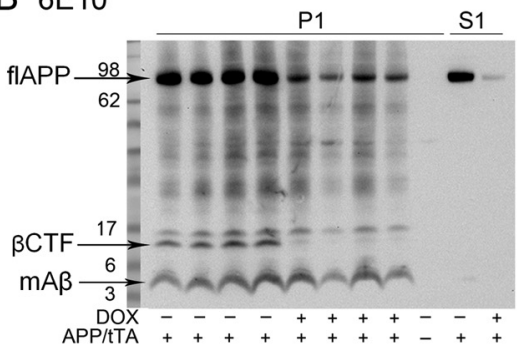

D C-term APP

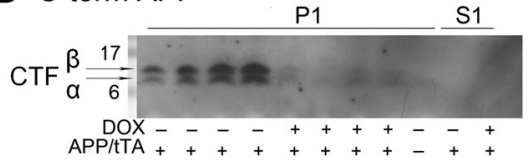

F 82E1

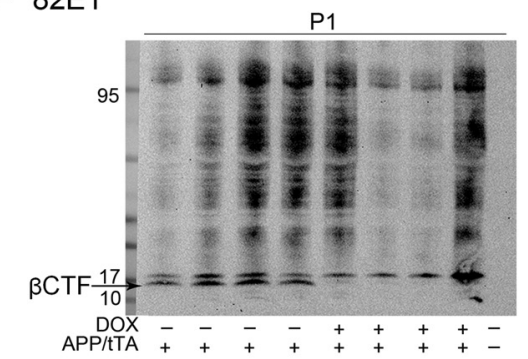

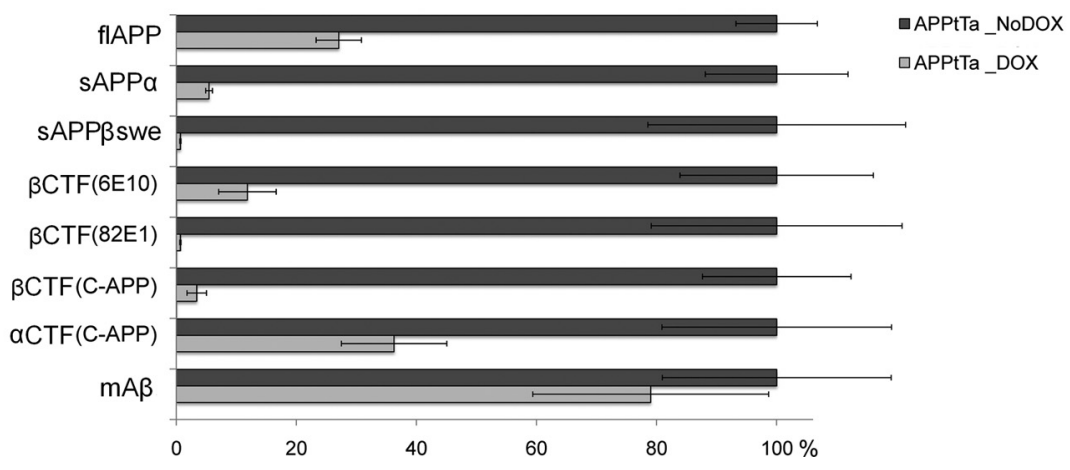

Figure 6. Immunoblot analysis of total protein extracts from cortical samples of mice that were behaviorally tested. All immunoblots include both cytosolic (S1) and membrane fractions (P1) and one control sample. $\boldsymbol{A}, \boldsymbol{B}$, Representative images of immunoblotting with $6 \mathrm{E} 10$ antibody, recognizing human monomer $A \beta$, transgene-derived full-length APP, and transgene-derived sAPP $\alpha$ from PBS-soluble ( $\boldsymbol{A})$ (S1, see Materials and Methods) and PBS-insoluble (B) (P1, see Materials and Methods) fractions. Fractions from NTg mice showed no immunoreactivity either in $\mathrm{S} 1$ or P1 fractions. DOX treatment resulted in decreased levels of high molecular weight APP (arrow), which includes membrane full-length APP (see P1, B) and soluble APP $\alpha$ (see S1, $\boldsymbol{A}$ ). The mAb 6E10 also detected $\beta$ CTFs ( $\sim 14 \mathrm{kDa}$, arrow), which disappeared after DOX treatment (B). C, The 6A1 antibody (IBL America) specifically recognizes soluble $\beta$ APP fragment with Swedish mutation cleaved by BACE1 (s $\beta$ APPswe) (arrow), which is detectable only in cytosolic fractions (S1) of brains from APPsi:tTA mice Off-DOX. D, Representative image of immunoblotting with C-terminal APP antibody (Millipore), recognizing the $\alpha$-CTF (C83) (lower arrow) and $\beta$-CTF (C99) (upper arrow) in membrane fraction; the levels of both dramatically decreased after DOX treatment. $\boldsymbol{E}, \boldsymbol{F}$, Representative images of immunoblotting with anti-human A $\beta \mathrm{N}$ terminal end specific antibody 82E1 (IBL America). This antibody does not recognize full-length APP. G, The results of densitometry analyses for monomer $A \beta, \alpha$-CTF, $\beta$ CTFs, SAPP $\beta$ swe, sAPP $\alpha$, and full-length APPsi in the immunoblots shown in $\boldsymbol{A}-\boldsymbol{F}$. The data are graphed with values for APPsi:TTA mice Off-DOX normalized to $100 \%$.

brains of these animals. These fractions would not be expected to contain significant levels of $\operatorname{sAPP} \alpha$ or $\operatorname{sAPP} \beta$. Immunoblots of boiled samples from the membrane fractions with $6 \mathrm{E} 10$ antibody (Fig. 10A) demonstrated that the levels of an APP species that migrated at the expected size of full-length APP (Fig. 10A, arrow) fell rapidly after DOX treatment as previously reported (Jankowsky et al., 2005). In addition to the full-length band, there was a smear of immunoreactivity in all lanes containing samples from APPsi:tTA mice (Fig. 10A, lanes 2-9). This smear of A $\beta$ 


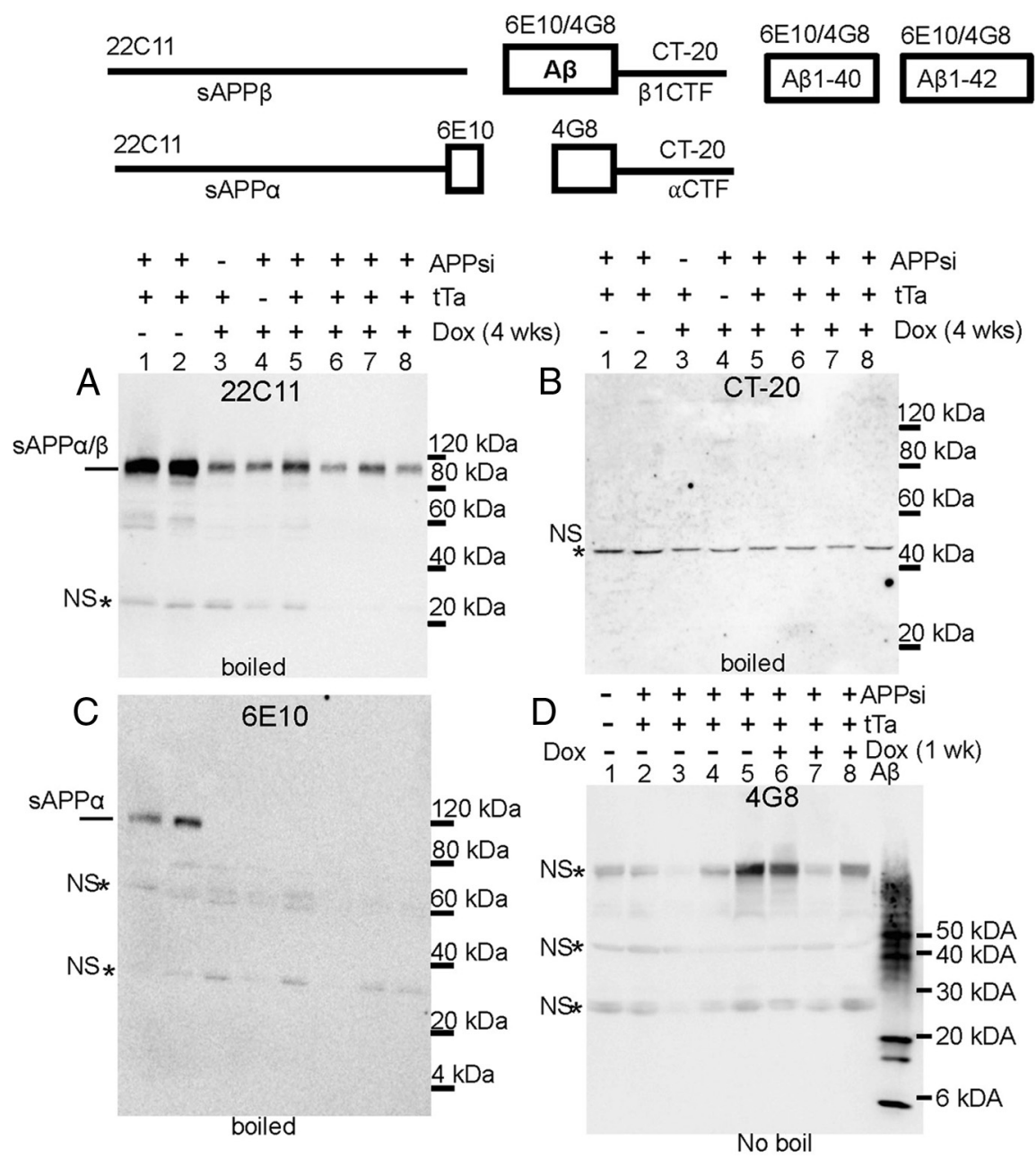

Figure 7. APP-immunoreactive species in water-extractable fractions from APPsi:tTA mice. As described in Materials and Methods, minced brain pieces, $\sim 500 \mathrm{mg}$, were soaked in $500 \mu \mathrm{l}$ of water for $1 \mathrm{~h}$ before centrifugation to separate soluble $A \beta$ species (water-extractable fraction). A total of $15 \mu \mathrm{l}$ of this fraction was analyzed by immunoblot with antibodies as noted in the figure. Mice that had been given DOX for 1 or 4 weeks are noted above the figure. $A$, Immunoblots of water-extractable fractions with $\mathrm{mAb} 22 \mathrm{C11}$, which recognizes an $\mathrm{N}$-terminal epitope in human and mouse APP. The major reactive band is secreted APP ectodomain ( $\alpha$ and $\beta$ recognized). $B$, A lack of reactivity with an antibody to the $C$ terminus of APP (CT20) confirms the absence of full-length APP in the water-extractable fractions. C, Reactivity to 6E10 demonstrates the presence of SAPPa in the water-extractable fractions and that this secreted ectodomain of APP disappears after DOX treatment (4 weeks). D, Immunoblot analysis of water-extractable fractions with $\mathrm{mAB} 4 \mathrm{G} 8$. In this example, to preserve any oligomeric structures, the samples were not boiled before electrophoresis. The gel also contains a positive control of $500 \mathrm{ng}$ of $A \beta 42$ aggregated in vitro. The $\mathrm{mAb} 4 \mathrm{G} 8$ is capable of recognizing full-length transgene-derived APP and endogenous mouse full-length APP. It does not recognize either endogenous or transgene-derived SAPP $\alpha$ or SAPP $\beta$. As noted in $\boldsymbol{B}$, water-extractable fractions do not contain full-length APP; thus, the identity of the band migrating at $>100$ $\mathrm{kDa}$ is uncertain and may be a nonspecific band (marked by asterisk). Similarly, the bands migrating at $\sim 50 \mathrm{kDa}$ and $\sim 25$ $\mathrm{kDa}$ also appear to be nonspecific bands (marked by asterisk).

immunoreactivity did not appreciably diminish after $7 \mathrm{~d}$ (Fig. $10 A, B$ ) or 4 weeks (Fig. 10C) of DOX treatment. There were also discrete bands that migrated between 20 and $30 \mathrm{kDa}$ in all lanes containing samples from APPsi:tTA mice (marked by an asterisk). In immunoblots of samples that were not boiled, it was harder to distinguish full-length APP (Fig. 10B, lanes 2-5). A smear of reactivity throughout the lanes containing sample from APPsi:tTA mice was observed with a couple of discrete bands detected at $20-30 \mathrm{kDa}$. In addition, there was a single, poorly resolved band that migrated $\angle 20 \mathrm{kDa}$ that was unique to APPsi: tTA mice Off-DOX (Fig. 10B, lanes 2-5, arrowhead). This band was identified as $\beta$ CTF because a band of similar size was seen in immunoblots of unboiled samples with the CT20 antibody, which recognizes a C-terminal epitope of APP, not $A \beta$ reactive (data not shown). The smear of $A \beta$ immunoreactivity in solubilized membrane fractions persisted after 4 weeks On-DOX with a similar persistence of discrete bands between 20 and $30 \mathrm{kDa}$ (Fig. 10C). Although we cannot be certain as to whether the methods of sample preparation may have influenced the banding pattern observed, these data indicated that there is an accumulation of multiple discrete forms of $A \beta$ immunoreactive entities that are stable in SDS and resistant to heat denaturation. These entities persisted after the new production of APP was inhibited.

\section{Discussion}

In the present study, we have determined the behavioral phenotypes present in 12- to 13-month-old APPsi:tTA mice and determined which phenotypes persist when expression of mutant APP has been acutely suppressed by DOX. We find that suppression of new APP/A $\beta$ synthesis in APPsi:tTA mice leads to rapidly improved performance in short-term memory tasks and that with sustained exposure to DOX the mice show superior performance in more demanding cognitive tasks that assess longterm spatial memory and working memory. As expected from previous work, amyloid plaque pathology persisted after DOX treatment with the levels of full-length APPsi derived from the transgene dropping quickly after treatment with DOX [as expected; (Jankowsky et al., 2005)]. In pathologic analyses of older APPsi;TA mice, we noted that intracellular immunoreactivity with $\mathrm{mAb}$ 6E10 remained stronger than one would expect at 1 week after DOX if all intracellular immunoreactivity was the result of antibody binding to full-length APP or $\beta$ CTFs of APP. However, by 5 weeks on DOX, intracellular mAb 6E10 staining fell to background levels. Somewhat unexpectedly, we also demonstrate a persistent, but relatively low, level of mobile, waterextractable, $A \beta 42$ in older APPsi:tTA mice treated with DOX for up to 4 weeks. Although we could not identify soluble $\mathrm{A} \beta$-immunoreactive entities that we were convinced were oligomeric forms of the peptide, we expect that the monomeric $\mathrm{A} \beta 42$ that is solubilizable in water or PBS would be in equilibrium with oligomeric $A \beta$; thus, such species probably exist but at relatively low levels. Our immunoblot analyses of PBS-insoluble fractions demonstrated immunoreactive entities of a size consistent with oligomeric $\mathrm{A} \beta$ assemblies that persisted after inhibition of new APP production. Overall, our studies demonstrate that cognitive impairment is relatively reversible, at least at the age studied, despite a persistence of several forms of $A \beta$ implicated in mediating cognitive impairment. 

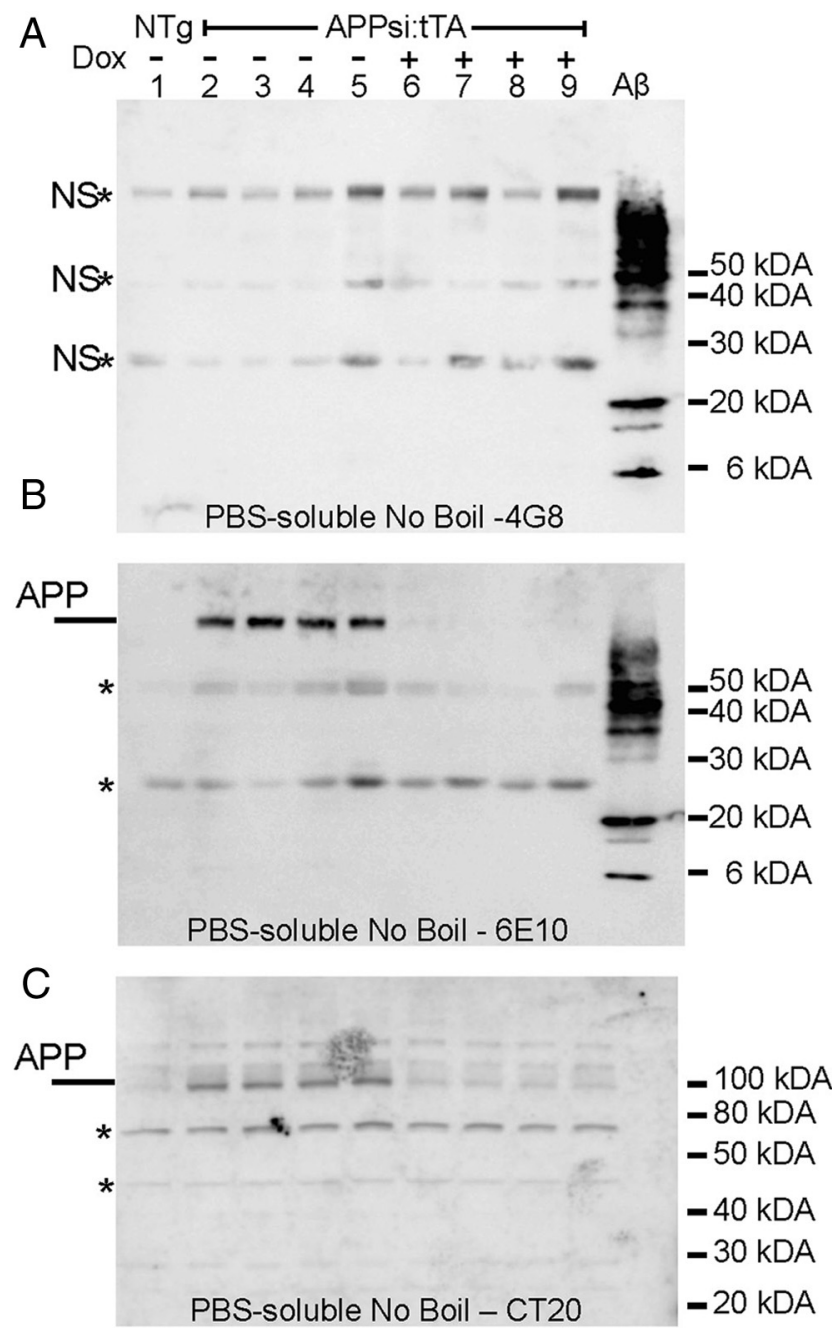

Figure 8. PBS-soluble $A \beta$-immunoreactive species in the brains of APPsi:tTA mice. To preserve any oligomeric structures as much as possible, the samples were not boiled before SDSPAGE. A-C, Immunoblots of PBS-soluble fractions probed with $m A b 4 G 8, m A b 6 E 10$, and APP C-terminal antibody CT-20 (see diagram in Fig. 7 for antibody specificity). A-C, Lane 1, NTg brain homogenate; Lanes 2-9, APPsi:tTA mice. Animals receiving D0X diets for 1 week are noted above in $\boldsymbol{A}$ (same in $\boldsymbol{B}$ and $\boldsymbol{C}$ ). Similar to the water-soluble fractions (Fig. 7D), the immunoblots with the mAb $4 G 8$ demonstrated three bands, none of which appears to be specific $(\boldsymbol{A})$, that were present in all genotypes at levels that do not change as expected with DOX treatment. $B$, In immunoblots with mAb 6E10, the major immunoreactive band is APP: inclusive of SAPP $\alpha / \beta$ and full-length APP as verified by immunostaining with (T-20 antibody (C). There are bands at $\sim 65$ and $45 \mathrm{kDa}$ (asterisks) that were present in immunoblots of all brain homogenates to varying degrees. The bands migrate very close to the expected size for lgG heavy and light chains.

\section{Mobile and immobile forms of $A \beta$ in the brains of APPsi:tTA mice}

Considerable effort was invested to detect soluble oligomeric $A \beta$ using methods that separated soluble, mobile, forms of $A \beta$ with as little tissue destruction as possible. In fractions generated by soaking minced brain, we detected abundant APP ectodomains, but we could find no other $A \beta$-immunoreactive band that was completely unique to APPsi:tTA mice and could be definitively identified as potentially representing oligomeric $A \beta$ assemblies. As described in Results, we estimate our limit of detection for solubilized $A \beta$ oligomers in immunoblots to be the equivalent of what would be formed by $30 \mathrm{ng}$ of $\mathrm{A} \beta$ assembled into a heterogeneous population of structures (see Fig. $7 D$ for an example).

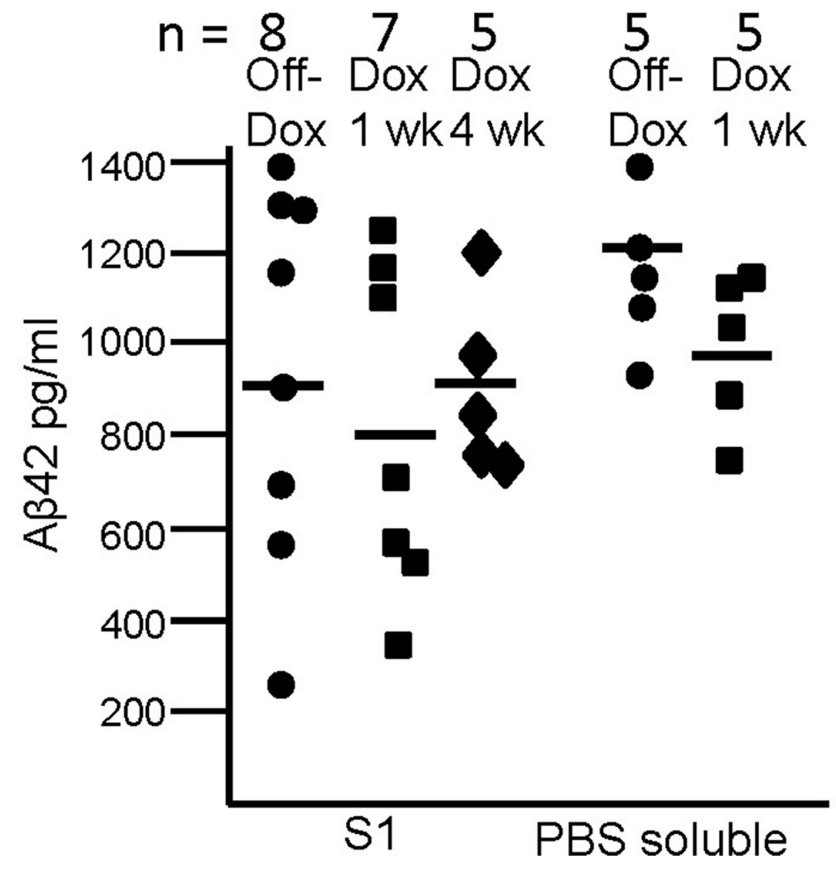

Figure 9. ELISA analysis of A $\beta 42$ levels in soluble fractions from APPsi:tTA mice. Scatter plot graph of A $\beta$ levels in water-extractable and PBS-soluble (S3) fractions from brains of APPsi:tTA mice on diets lacking DOX (No DOX) or on diets with DOX for 1 week as noted. A $\beta$ levels were measured as described in Materials and Methods.

The most abundant-immunoreactive forms of $A \beta$ that were specific to transgene positive mice, and of a size consistent with oligomeric assemblies were found in PBS-insoluble membrane fractions. In samples that were boiled, we routinely detected a pair of bands of $\sim 22-26 \mathrm{kDa}$ that were specific to the APPsi:tTA mice. However, we cannot know whether these assemblies of $A \beta$ really existed in the brain or were generated by tissue homogenization and sample preparation. Also, we lack precise information regarding the composition of these bands. Importantly for this study, if these immunoreactive bands are oligomeric $\mathrm{A} \beta$ assemblies, the abundance of these forms of $A \beta$ does not change after DOX treatment; thus, they persisted after new production of APPsi was inhibited.

\section{Relationship between APP and A $\beta$ in cognitive performance} of transgenic mouse models

There have been several reports in the literature in which the Tg2576 model has been treated with a BACE1 inhibitor or $\gamma$-secretase inhibitor (GSI) followed by assessments of cognitive behavior (Fukumoto et al., 2010; Takahashi et al., 2010; Balducci et al., 2011; Chang et al., 2011; Mitani et al., 2012). Comparison of these studies to our present work is often difficult because few of these studies have examined the effect of the inhibitors in mice with high amyloid burden. In younger Tg2576 mice, treatment with BACE 1 inhibitors, GSIs, or $\gamma$-secretase modulators, have produced varied levels of improvement in performance in cognitive tasks and varied reductions in levels of $\mathrm{A} \beta$. Only one study has examined GSIs in mice that have robust amyloid deposition (Comery et al., 2005). In this work, Tg2576 mice were shown to develop deficits in long-term, but not short-term, memory in a contextual fear conditioning paradigm between the ages of 12 and 16 weeks. At 16 weeks of age, the levels of $A \beta$ will have begun to rise, indicating that there are beginnings of $A \beta$ assembly into more stable structures (Kawarabayashi et al., 2001). Suppressing the production of $\mathrm{A} \beta 40$ and 42 by $\sim 30 \%$ with DAPT, a GSI, in 

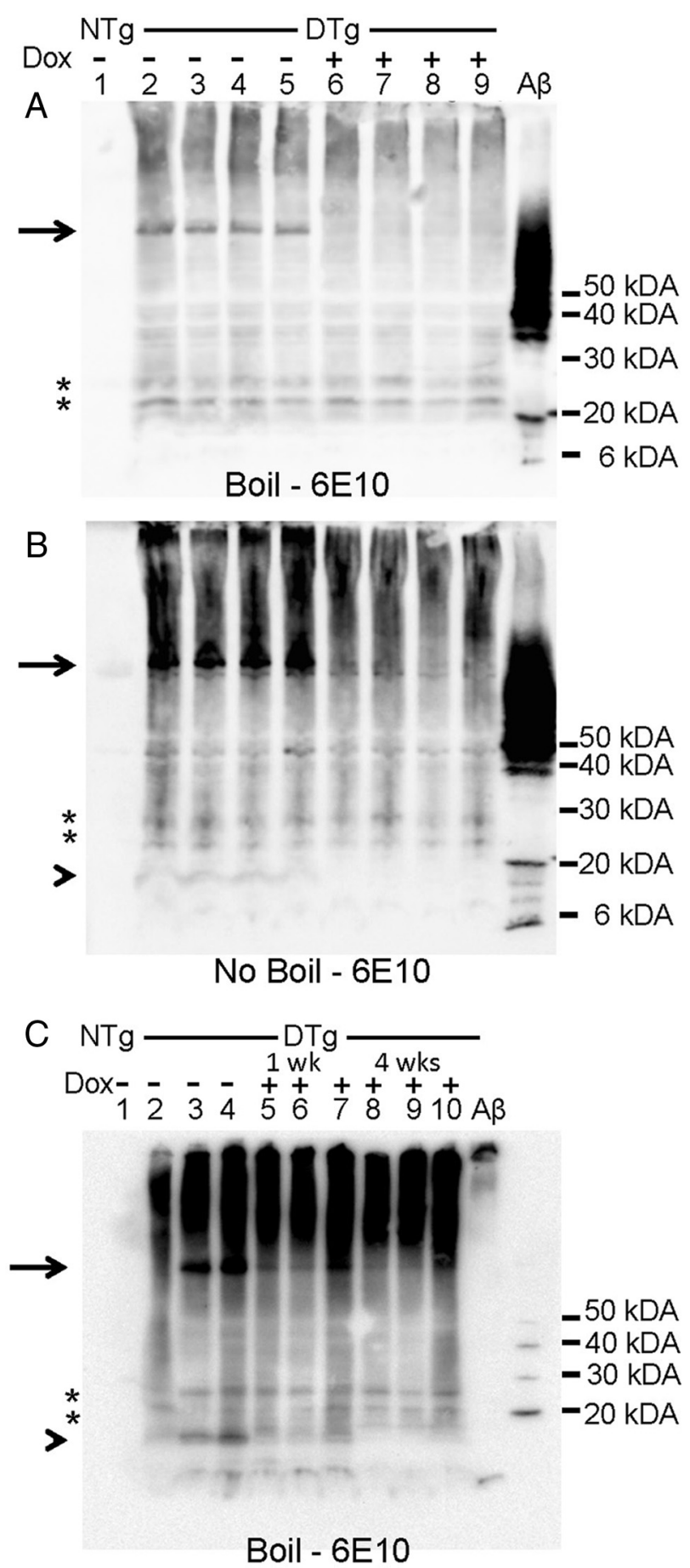

Figure 10. $\quad A \beta$-immunoreactive species in PBS-insoluble fractions of brain from APPsi:tTA mice. $\boldsymbol{A}$-C, Immunoblots of PBS-insoluble fractions with mAb 6E10 (see diagram in Fig. 7 for antibody specificity), which detects APP derivatives produced by the transgene (does not recognize endogenous APP or its derivatives). Suspensions of PBS-insoluble fractions from brain were mixed with $4 \times$ Laemmli buffer, boiled before loading $(\boldsymbol{A}, \boldsymbol{C})$ or loaded directly $(\boldsymbol{B})$, transferred to membrane, and analyzed by immunoblot. $\boldsymbol{A}-\boldsymbol{C}$, Lane 1, NTg brain homogenate. $\boldsymbol{A}, \boldsymbol{B}$, Lanes 2-9, APPsi:tTA mice. Animals receiving D0X diets for 1 week are noted above $\boldsymbol{A}$ (same in B). C, Lanes 2-10, APPsi:tTA mice. Animals receiving D0X diets for 1 or 4 weeks are noted above panel. $\boldsymbol{C}$, The blot is overexposed to reveal lower molecular weight bands. A band that migrates to the size expected for full-length APP was observed in APPsi:tTA mice Off-DOX; this band was absent in mice On-DOX for 1 week (A). In the samples that were not boiled from mice 0ff-D0X, we detected a band of $\sim 10 \mathrm{kDa}$ (arrowhead) that was absent in mice 0n-D0X. This band was also seen in blots with the (T-20 antibody (data not shown) and likely represents an APP C-terminal fragment. Discrete bands that could represent stable oligomeric assemblies of $A \beta$ are noted by asterisks. the $\mathrm{Tg} 2576$ model in these early phases of amyloid accumulation, produces rapid improvements of long-term contextual memory (Comery et al., 2005). The beneficial effects of this GSI were also observed at later ages when amyloid deposits are relatively high. Note that the GSI would be expected to cause $\beta$ CTFs of APP to accumulate and would not affect levels of $\operatorname{APP}, \operatorname{sAPP} \alpha$, or s $\beta$ APPswe. Thus, in the Tg2576 model, the improvements in long-term memory were correlated to modest reductions in the generation of $\mathrm{A} \beta$ without an obvious mechanism for affecting the levels of other APP derivatives.

Our findings convincingly show, in a completely distinct model, that impairments in both short- and long-term memory can be rapidly reversed when the new production of $\mathrm{APP} / \mathrm{A} \beta$ is inhibited. The APPsi:tTA model differs from the Tg2576 model in the severity of amyloid deposition at the time of testing. In our model, the level of accumulated $\mathrm{A} \beta$ and amyloid burdens were high. The unique features of the APPsi:tTA model reveal that cognitive performance is not inextricably linked to the levels of $\mathrm{A} \beta$ peptide as we find persistent levels of soluble and insoluble $\mathrm{A} \beta$ peptides in mice that show remarkable cognitive improvement when new APP/A $\beta$ synthesis is suppressed. In our APPsi:tTA mice, the most abundant derivatives of APP that were lost after new APPsi synthesis was suppressed were full-length APP, soluble APP ectodomains, and C-terminal APP fragments. Although it is possible that the low abundance soluble forms of $\mathrm{A} \beta$ (monomer or oligomer) possess a disproportionate bioactivity in regard to cognitive function, there is no particular basis to rule out a role for the more abundant derivatives, particularly because the loss of these derivatives appears to be highly correlated to cognitive performance.

Derivatives of APP other than A $\beta$ have recently been implicated as potentially mediating cognitive impairment in mice. In mice that model familial Danish dementia, in which an interaction between mutant BRI2 and APP was suggested to mediate cognitive dysfunction, inhibition of BACE1, but not $\gamma$-secretase, restores performance in cognitive function (Tamayev and D'Adamio, 2012; Tamayev et al., 2012). Inhibition of $\boldsymbol{\gamma}$-secretase lead to an accumulation of $\beta$ CTFs of APP, which correlated with diminished performance in short-term memory (Tamayev and D'Adamio, 2012). Mice that express a recombinant transgene that encodes an engineered APP $\beta$ CTF, lacking a signal sequence for proper membrane insertion (Kammesheidt et al., 1992), have been reported to show deficits in cognitive behavior (BergerSweeney et al., 1999). However, mice that express an engineered APP $\beta$ CTF that included a signal sequence for proper membrane insertion lack evidence of neurodegeneration; cognitive behavior in these mice has not been reported (Rutten et al., 2003). Deyts et al. (2012) recently demonstrated that APP $\beta$ CTFs can mediate G-protein signaling and that GSI treatment increased the levels of APP $\beta C T F s$, leading to increased neurite outgrowth. Collectively, these studies indicate a potential role for APP $\beta$ CTFs in neuronal signaling and cognitive performance. Although we found that the loss of APP $\beta$ CTFs was one correlate to improved memory performance in the APPsi:tTA mice, the loss of full-length APP and sAPP ectodomains occurred at relatively the same rate.

In conclusion, our studies of cognitive performance in mice that model Alzheimer amyloidosis have produced a body of work that paints a complicated picture of how the accumulation of $\mathrm{A} \beta$ may impair performance of mice in memory tasks. Although the accumulation of $\mathrm{A} \beta$ seems to be essential in mediating cognitive impairment, emerging data indicate that other derivatives of APP may also play some role. Although one would like to be able to fit all the data into a unifying mechanism, it is possible that $\mathrm{A} \beta$ and 
derivatives of APP can act via multiple mechanisms to diminish cognitive function in mice, with some of these mechanisms being unrelated to the basis for cognitive symptoms in humans. Encouragingly, we find that mice with persistent pathologic amyloid deposits and soluble, mobile, forms of $\mathrm{A} \beta 42$ can show normal short-term memory with preserved, albeit imperfect, long-term memory if new APP/A $\beta$ synthesis is inhibited. These findings predict that cognitive impairment mediated solely by the accumulation of $A \beta$ and/or amyloid could be reversible and need not require the clearance of existing amyloid deposits if such deficits are mediated by a short-lived, newly made species of $\mathrm{A} \beta$. Alternatively, our findings could also be interpreted as evidence that the accumulation of $\mathrm{A} \beta$ and amyloid, by itself, only minimally impacts cognition in mice, a finding that is somewhat more in line with human data on cognition and amyloid pathology (Moore et al., 2012).

\section{References}

Arendash GW, King DL, Gordon MN, Morgan D, Hatcher JM, Hope CE, Diamond DM (2001) Progressive, age-related behavioral impairments in transgenic mice carrying both mutant amyloid precursor protein and presenilin-1 transgenes. Brain Res 891:42-53. CrossRef Medline

Balducci C, Mehdawy B, Mare L, Giuliani A, Lorenzini L, Sivilia S, Giardino L, Calzà L, Lanzillotta A, Sarnico I, Pizzi M, Usiello A, Viscomi AR, Ottonello S, Villetti G, Imbimbo BP, Nisticò G, Forloni G, Nisticò R (2011) The $\gamma$-secretase modulator CHF5074 restores memory and hippocampal synaptic plasticity in plaque-free Tg2576 mice. J Alzheimers Dis 24:799816. CrossRef Medline

Bentahir M, Nyabi O, Verhamme J, Tolia A, Horré K, Wiltfang J, Esselmann H, De Strooper B (2006) Presenilin clinical mutations can affect $\gamma$-secretase activity by different mechanisms. J Neurochem 96:732-742. CrossRef Medline

Berger-Sweeney J, McPhie DL, Arters JA, Greenan J, Oster-Granite ML, Neve RL (1999) Impairments in learning and memory accompanied by neurodegeneration in mice transgenic for the carboxyl-terminus of the amyloid precursor protein. Brain Res Mol Brain Res 66:150-162. Medline

Chang Q, Gold PE (2003) Switching memory systems during learning: changes in patterns of brain acetylcholine release in the hippocampus and striatum in rats. J Neurosci 23:3001-3005. Medline

Chang WP, Huang X, Downs D, Cirrito JR, Koelsch G, Holtzman DM, Ghosh AK, Tang J (2011) $\beta$-Secretase inhibitor GRL-8234 rescues age-related cognitive decline in APP transgenic mice. FASEB J 25:775-784. CrossRef Medline

Chen G, Chen KS, Knox J, Inglis J, Bernard A, Martin SJ, Justice A, McConlogue L, Games D, Freedman SB, Morris RG (2000) A learning deficit related to age and $\beta$-amyloid plaques in a mouse model of Alzheimer's disease. Nature 408:975-979. CrossRef Medline

Citron M, Westaway D, Xia W, Carlson G, Diehl T, Levesque G, JohnsonWood K, Lee M, Seubert P, Davis A, et al. (1997) Mutant presenilins of Alzheimer's disease increase production of 42-residue amyloid $\beta$-protein in both transfected cells and transgenic mice. Nat Med 3:67-72. CrossRef Medline

Citron M, Oltersdorf T, Haass C, McConlogue L, Hung AY, Seubert P, VigoPelfrey C, Lieberburg I, Selkoe DJ (1992) Mutation of the $\beta$-amyloid precursor protein in familial Alzheimer's disease increases $\beta$-protein production. Nature 360:672-674. CrossRef Medline

Comery TA, Martone RL, Aschmies S, Atchison KP, Diamantidis G, Gong X, Zhou H, Kreft AF, Pangalos MN, Sonnenberg-Reines J, Jacobsen JS, Marquis KL (2005) Acute $\gamma$-secretase inhibition improves contextual fear conditioning in the Tg2576 mouse model of Alzheimer's disease. J Neurosci 25:8898-8902. CrossRef Medline

Conrad CD, Galea LA, Kuroda Y, McEwen BS (1996) Chronic stress impairs rat spatial memory on the $\mathrm{Y}$ maze, and this effect is blocked by tianeptine pretreatment. Behav Neurosci 110:1321-1334. CrossRef Medline

Cook D, Kesner RP (1988) Caudate nucleus and memory for egocentric localization. Behav Neural Biol 49:332-343. CrossRef Medline

De Jonghe C, Esselens C, Kumar-Singh S, Craessaerts K, Serneels S, Checler F, Annaert W, Van Broeckhoven C, De Strooper B (2001) Pathogenic APP mutations near the $\gamma$-secretase cleavage site differentially affect Abeta secretion and APP C-terminal fragment stability. Hum Mol Genet 10: 1665-1671. CrossRef Medline

Dellu F, Fauchey V, Le Moal M, Simon H (1997) Extension of a new two trial memory task in the rat: influence of environmental context on recognition processes. Neurobiol Learn Mem 67:112-120. CrossRef Medline

Deyts C, Vetrivel KS, Das S, Shepherd YM, Dupré DJ, Thinakaran G, Parent AT (2012) Novel $G \alpha S$-protein signaling associated with membranetethered amyloid precursor protein intracellular domain 1. J Neurosci 32:1714-1729. CrossRef Medline

Di Fede G, Catania M, Morbin M, Rossi G, Suardi S, Mazzoleni G, Merlin M, Giovagnoli AR, Prioni S, Erbetta A, et al. (2009) A recessive mutation in the APP gene with dominant-negative effect on amyloidogenesis 11. Science 323:1473-1477. CrossRef Medline

Dodart JC, Meziane H, Mathis C, Bales KR, Paul SM, Ungerer A (1999) Behavioral disturbances in transgenic mice overexpressing the V717F $\beta$-amyloid precursor protein. Behav Neurosci 113:982-990. CrossRef Medline

Ennaceur A, Delacour J (1988) A new one-trial test for neurobiological studies of memory in rats. 1: Behavioral data. Behav Brain Res 31:47-59. CrossRef Medline

Eriksen JL, Janus CG (2007) Plaques, tangles, and memory loss in mouse models of neurodegeneration. Behav Genet 37:79-100. CrossRef Medline

Fukumoto H, Takahashi H, Tarui N, Matsui J, Tomita T, Hirode M, Sagayama M, Maeda R, Kawamoto M, Hirai K, Terauchi J, Sakura Y, Kakihana M, Kato K, Iwatsubo T, Miyamoto M (2010) A noncompetitive BACE1 inhibitor TAK-070 ameliorates Abeta pathology and behavioral deficits in a mouse model of Alzheimer's disease. J Neurosci 30:11157-11166. CrossRef Medline

Gimbel DA, Nygaard HB, Coffey EE, Gunther EC, Laurén J, Gimbel ZA, Strittmatter SM (2010) Memory impairment in transgenic Alzheimer mice requires cellular prion protein. J Neurosci 30:6367-6374. CrossRef Medline

Guntern R, Bouras C, Hof PR, Vallet PG (1992) An improved thioflavine S method for staining neurofibrillary tangles and senile plaques in Alzheimer's disease. Experientia 48:8-10. CrossRef Medline

Han HJ, Allen CC, Buchovecky CM, Yetman MJ, Born HA, Marin MA, Rodgers SP, Song BJ, Lu HC, Justice MJ, Probst FJ, Jankowsky JL (2012) Strain background influences neurotoxicity and behavioral abnormalities in mice expressing the tetracycline transactivator. J Neurosci 32:1057410586. CrossRef Medline

Horikoshi Y, Sakaguchi G, Becker AG, Gray AJ, Duff K, Aisen PS, Yamaguchi H, Maeda M, Kinoshita N, Matsuoka Y (2004) Development of Abeta terminal end-specific antibodies and sensitive ELISA for Abeta variant. Biochem Biophys Res Commun 319:733-737. CrossRef Medline

Hsiao K, Chapman P, Nilsen S, Eckman C, Harigaya Y, Younkin S, Yang F, Cole G (1996) Correlative memory deficts, $A \beta$ elevation and amyloid plaques in transgenic mice. Science 274:99-102. CrossRef Medline

Iwatsubo T, Odaka A, Suzuki N, Mizusawa H, Nukina N, Ihara Y (1994) Visualization of $A \beta 42(43)$-positive and $A \beta 40$-positive senile plaques with end-specific $\mathrm{A} \beta$-monoclonal antibodies: evidence that an initially deposited $A \beta$ species is $A \beta 1-42(43)$. Neuron 13:45-53. CrossRef Medline

Jankowsky JL, Savonenko A, Schilling G, Wang J, Xu G, Borchelt DR (2002) Transgenic mouse models of neurodegenerative disease: opportunities for therapeutic development. Curr Neurol Neurosci Rep 2:457-464. CrossRef Medline

Jankowsky JL, Slunt HH, Gonzales V, Savonenko AV, Wen JC, Jenkins NA, Copeland NG, Younkin LH, Lester HA, Younkin SG, Borchelt DR (2005) Persistent amyloidosis following suppression of Abeta production in a transgenic model of Alzheimer disease. PLoS Med 2:e355. CrossRef Medline

Janus C, Pearson J, McLaurin J, Mathews PM, Jiang Y, Schmidt SD, Chishti MA, Horne P, Heslin D, French J, Mount HT, Nixon RA, Mercken M, Bergeron C, Fraser PE, St George-Hyslop P, Westaway D (2000) A $\beta$ peptide immunization reduces behavioural impairment and plaques in a model of Alzheimer's disease. Nature 408:979-982. CrossRef Medline

Kammesheidt A, Boyce FM, Spanoyannis AF, Cummings BJ, Ortegón M, Cotman C, Vaught JL, Neve RL (1992) Deposition of $\beta / A 4$ immunoreactivity and neuronal pathology in transgenic mice expressing the carboxyterminal fragment of the Alzheimer amyloid precursor in the brain. Proc Natl Acad Sci U S A 89:10857-10861. CrossRef Medline

Kawarabayashi T, Younkin LH, Saido TC, Shoji M, Ashe KH, Younkin SG (2001) Age-dependent changes in brain, CSF, and plasma amyloid $(\beta)$ 
protein in the $\mathrm{Tg} 2576$ transgenic mouse model of Alzheimer's disease. J Neurosci 21:372-381. Medline

Kayed R, Head E, Sarsoza F, Saing T, Cotman CW, Necula M, Margol L, Wu J, Breydo L, Thompson JL, Rasool S, Gurlo T, Butler P, Glabe CG (2007) Fibril specific, conformation dependent antibodies recognize a generic epitope common to amyloid fibrils and fibrillar oligomers that is absent in prefibrillar oligomers. Mol Neurodegener 2:18. CrossRef Medline

Kim KS, Wen GY, Bancher C, Chen CMJ, Sapienza VJ, Hong H, Wisniewski HM (1990) Detection and quantitation of amyloid B-peptide with 2 monoclonal antibodies. Neurosci Res Commun 7:113-122.

Klyubin I, Betts V, Welzel AT, Blennow K, Zetterberg H, Wallin A, Lemere CA, Cullen WK, Peng Y, Wisniewski T, Selkoe DJ, Anwyl R, Walsh DM, Rowan MJ (2008) Amyloid $\beta$ protein dimer-containing human CSF disrupts synaptic plasticity: prevention by systemic passive immunization. J Neurosci 28:4231-4237. CrossRef Medline

Kwok JB, Li QX, Hallupp M, Whyte S, Ames D, Beyreuther K, Masters CL, Schofield PR (2000) Novel Leu723Pro amyloid precursor protein mutation increases amyloid $\beta 42(43)$ peptide levels and induces apoptosis. Ann Neurol 47:249-253. CrossRef Medline

Laird FM, Cai H, Savonenko AV, Farah MH, He K, Melnikova T, Wen H, Chiang HC, Xu G, Koliatsos VE, Borchelt DR, Price DL, Lee HK, Wong PC (2005) BACE1, a major determinant of selective vulnerability of the brain to amyloid- $\beta$ amyloidogenesis, is essential for cognitive, emotional, and synaptic functions. J Neurosci 25:11693-11709. CrossRef Medline

Li H, Wolfe MS, Selkoe DJ (2009) Toward structural elucidation of the $\gamma$-secretase complex. Structure 17:326-334. CrossRef Medline

Lichtenthaler SF, Haass C, Steiner H (2011) Regulated intramembrane proteolysis: lessons from amyloid precursor protein processing. J Neurochem 117:779-796. CrossRef Medline

McDonald JM, Savva GM, Brayne C, Welzel AT, Forster G, Shankar GM, Selkoe DJ, Ince PG, Walsh DM (2010) The presence of sodium dodecyl sulphate-stable Abeta dimers is strongly associated with Alzheimer-type dementia. Brain 133:1328-1341. CrossRef Medline

McGowan E, Pickford F, Kim J, Onstead L, Eriksen J, Yu C, Skipper L, Murphy MP, Beard J, Das P, Jansen K, Delucia M, Lin WL, Dolios G, Wang R, Eckman CB, Dickson DW, Hutton M, Hardy J, Golde T (2005) A $\beta 42$ is essential for parenchymal and vascular amyloid deposition in mice. Neuron 47:191-199. CrossRef Medline

Melnikova T, Savonenko A, Wang Q, Liang X, Hand T, Wu L, Kaufmann WE, Vehmas A, Andreasson KI (2006) Cycloxygenase-2 activity promotes cognitive deficits but not increased amyloid burden in a model of Alzheimer's disease in a sex-dimorphic pattern. Neuroscience 141:1149-1162. CrossRef Medline

Mitani Y, Yarimizu J, Saita K, Uchino H, Akashiba H, Shitaka Y, Ni K, Matsuoka N (2012) Differential effects between $\gamma$-secretase inhibitors and modulators on cognitive function in amyloid precursor proteintransgenic and nontransgenic mice. J Neurosci 32:2037-2050. CrossRef Medline

Moechars D, Dewachter I, Lorent K, Reversé D, Baekelandt V, Naidu A, Tesseur I, Spittaels K, Haute CV, Checler F, Godaux E, Cordell B, Van Leuven F (1999) Early phenotypic changes in transgenic mice that overexpress different mutants of amyloid precursor protein in brain. J Biol Chem 274:6483-6492. CrossRef Medline

Moore BD, Chakrabarty P, Levites Y, Kukar TL, Baine AM, Moroni T, Ladd TB, Das P, Dickson DW, Golde TE (2012) Overlapping profiles of Abeta peptides in the Alzheimer's disease and pathological aging brains. Alzheimers Res Ther 4:18. CrossRef Medline

Packard MG, McGaugh JL (1996) Inactivation of hippocampus or caudate nucleus with lidocaine differentially affects expression of place and response learning. Neurobiol Learn Mem 65:65-72. CrossRef Medline

Pinnix I, Musunuru U, Tun H, Sridharan A, Golde T, Eckman C, Ziani-Cherif C, Onstead L, Sambamurti K (2001) A novel $\gamma$-secretase assay based on detection of the putative C-terminal fragment- $\gamma$ of amyloid beta protein precursor. J Biol Chem 276:481-487. CrossRef Medline
Rodgers SP, Born HA, Das P, Jankowsky JL (2012) Transgenic APP expression during postnatal development causes persistent locomotor hyperactivity in the adult. Mol Neurodegener 7:28. CrossRef Medline

Rogaev EI, Sherrington R, Rogaeva EA, Levesque G, Ikeda M, Liang Y, Chi H, Lin C, Holman K, Tsuda T, et al. (1995) Familial Alzheimer's disease in kindreds with missense mutations in a gene on chromosome 1 related to the Alzheimer's disease type 3 gene. Nature 376:775-778. CrossRef Medline

Rutten BP, Wirths O, Van de Berg WD, Lichtenthaler SF, Vehoff J, Steinbusch HW, Korr H, Beyreuther K, Multhaup G, Bayer TA, Schmitz C (2003) No alterations of hippocampal neuronal number and synaptic bouton number in a transgenic mouse model expressing the beta-cleaved C-terminal APP fragment. Neurobiol Dis 12:110-120. CrossRef Medline

Savonenko AV, Xu GM, Price DL, Borchelt DR, Markowska AL (2003) Normal cognitive behavior in two distinct lines of transgenic mice hyperexpressing mutant APPswe. Neurobiol Dis 12:194-211. CrossRef Medline

Savonenko A, Xu GM, Melnikova T, Morton JL, Gonzales V, Wong MP, Price DL, Tang F, Markowska AL, Borchelt DR (2005) Episodic-like memory deficits in the APPswe/PS1dE9 mouse model of Alzheimer's disease: relationships to $\beta$-amyloid deposition and neurotransmitter abnormalities. Neurobiol Dis 18:602-617. CrossRef Medline

Scheuner D, Eckman C, Jensen M, Song X, Citron M, Suzuki N, Bird TD, Hardy J, Hutton M, Kukull W, et al. (1996) Secreted amyloid $\beta$-protein similar to that in the senile plaques of Alzheimer's disease is increased in vivo by the presenilin 1 and 2 and APP mutations linked to familial Alzheimer's disease. Nat Med 2:864-870. CrossRef Medline

Selkoe DJ, Podlisny MB (2002) Deciphering the genetic basis of Alzheimer's disease. Annu Rev Genomics Hum Genet 3:67-99. CrossRef Medline

Suzuki N, Cheung TT, Cai XD, Odaka A, Otvos L Jr, Eckman C, Golde TE, Younkin SG (1994) An increased percentage of long amyloid $\beta$ protein secreted by familial amyloid $\beta$ protein precursor $\left(\beta \mathrm{APP}_{717}\right)$ mutants. Science 264:1336-1340. CrossRef Medline

Takahashi H, Fukumoto H, Maeda R, Terauchi J, Kato K, Miyamoto M (2010) Ameliorative effects of a non-competitive BACE1 inhibitor TAK070 on Abeta peptide levels and impaired learning behavior in aged rats. Brain Res 1361:146-156. CrossRef Medline

Tamayev R, D'Adamio L (2012) Inhibition of $\gamma$-secretase worsens memory deficits in a genetically congruous mouse model of Danish dementia. Mol Neurodegener 7:19. CrossRef Medline

Tamayev R, Matsuda S, Arancio O, D’Adamio L (2012) $\beta$ - but not $\gamma$-secretase proteolysis of APP causes synaptic and memory deficits in a mouse model of dementia. EMBO Mol Med 4:171-179. CrossRef Medline

Westerman MA, Cooper-Blacketer D, Mariash A, Kotilinek L, Kawarabayashi T, Younkin LH, Carlson GA, Younkin SG, Ashe KH (2002) The relationship between Abeta and memory in the Tg2576 mouse model of Alzheimer's disease. J Neurosci 22:1858-1867. Medline

Xia W, Yang T, Shankar G, Smith IM, Shen Y, Walsh DM, Selkoe DJ (2009) A specific enzyme-linked immunosorbent assay for measuring $\beta$-amyloid protein oligomers in human plasma and brain tissue of patients with Alzheimer disease. Arch Neurol 66:190-199. CrossRef Medline

Xu G, Green CC, Fromholt SE, Borchelt DR (2012) Reduction of lowdensity lipoprotein receptor-related protein (LRP1) in hippocampal neurons does not proportionately reduce, or otherwise alter, amyloid deposition in APPswe/PS1dE9 transgenic mice. Alzheimers Res Ther 4:12. CrossRef Medline

Zhou L, Brouwers N, Benilova I, Vandersteen A, Mercken M, Van Laere K, Van Damme P, Demedts D, Van Leuven F, Sleegers K, Broersen K, Van Broeckhoven C, Vandenberghe R, De Strooper B (2011) Amyloid precursor protein mutation E682K at the alternative $\beta$-secretase cleavage $\beta$ '-site increases Abeta generation. EMBO Mol Med 3:291-302. CrossRef Medline 